[AmNais N. Y. ACAD. SCs, Vol. XIV, No. 2, pp. 1-52, June 5, 1901.]

\title{
REPORT ON THE HEXACTINIE OF THE COLUMBIA UNIVERSITY EXPEDITION TO PUGET SOUND DURING THE SUMMER OF 1896
}

\author{
J. Playfair McMurrich
}

[Plates I-III ; text figures I-II.]

(Read November 14,2898 )

In presenting this report I must testify to the pleasure I experienced in studying the collection, a pleasure due both to the admirable preservation of all the specimens and to the careful notes and drawings-which accompanied them. The credit for both belongs to Dr. Gary N. Calkins. The method employed for the preservation was a preliminary immersion in magnesium sulphate as suggested by Tullberg, followed by fixation and preservation in formalin. Nearly all the specimens were beauti . fully expanded and the histological preservation was excellent. The only disadvantage presented by the method, probably due to the formalin, was the failure of preparations to stain with the ordinary carmine stains, such as Grenacher's borax carmine; hæmatoxylin stains acted admirably, however.

I wish also to express my thanks to Mr. Alexander Agassiz for his kindness in loaning me, for comparison, a number of drawings of West Coast forms prepared from livings specimens several years ago.

The manuscript of this paper was originally completed in April, 1898, but I have taken advantage of the long delay which has occurred in its publication to introduce some references to papers which have appeared more recently, and also to correct a grievqus misapprehension into which I had fallen with regard to the systematic position of Epiactis prolifera. The nature of this misapprehension is explained in the description of the species.

Ansals N, Y, ACAD. SCI., XIV, June 5, 190I-1. 
MCMURRICH

\section{HEXACTINIE}

\section{Actinine}

\section{Family SAGARTILDE}

Actininx with adherent base; with a mesoglceal (rarely a weak endodermal sphincter); and with acontia which are emitted either through the mouth alone or also through special openings (cinclides) in the column wall.

The family Sagartidæ, since its first establishment by Gosse in 1858 , has undergone certain changes which have for the nost part been fully discussed by various authors. "Within recent years there has been introduced a subdivision into subfamilies. The family Phellinze of Verrill ('68) has been added as a subfamily and the remaining forms assigned to the subfamilies Sagartiinz or Metridinz according as they possessed more than six pairs of perfect mesenteries or only that number (Carlgren '93); a subfamily Chondractinina had previously been proposed by Haddon ('89); Simon ('92), recognized two subfamilies Aiptasiinz and Sagartiinz, the former characterized by possessing an endodermal sphincter or none at all; and, finally, Haddon accepts all the proposed subdivisions, admitting the existence of no less than five subfamilies.

It seems to me that the subdivision proposed by Carlgren is that to be preferred. I do not think the recognition of a subfamily Aiptasiina is advisable since several undoubted Aiptasias are known to possess a mesoglceal sphincter, as, for instance $A$. pallida (Ag.), $A$. sp. (from the Bermudas, McM.) and $A$. lucida (Duch. \& Mich.) Duerden. In all these, it is true, the muscle is exceeding weak, but it nevertheless is present, and its absence in certain species is merely the fulfillment of the reduction of it which is characteristic of the genus. A separation of the forms with no mesoglceal sphincter would be an act of violence, and, if this be avoided, the genus Aiptasin is properly referable to the Metridiinx.

In the second place, it does not seem to me that a recognition of the Phelliinz and Chondractiniinz as distinct subfamilies is necessary. Both lack cinclides, have a coriaceous column wall 
provided with an epidermis, a distinct mesogloeal sphincter and only 6 pairs of perfect mesenteries. Haddon makes the distinction rest upon the occurrence of gonads in the mesenteries of the first cycle which he has found in certain Phellias. It does' not seem to me that this peculiarity deserves the importance that Haddon has assigned to it, and I may again refer to the genus Aiptasia as providing ammunition for use against my friend's proposition. In $A$. pallida and in $A$. sp. (Bermudas, McM.) gonads occur in the mesenteries of the first cycle, and yet I imagine that no one would therefore suggest the assignment of these species to a different subfamily than that which shelters A. annulata, etc. We may, apparently, find occasionally an infringement of the right of sterility usually enjoyed by the firstcycle mesenteries, but it does not seem to me that we should at present legitimize the infringement by granting it the rank of a subfamily characteristic.

In the present collection I have found no representatives of either the Sagartinze or Phelliinz, but a representative of the Metridina occurred.

Subfamily Metridine; Carlgren.

Sagartiidx in which the column wall is perforated by cinclides and in which only the mesenteries of the first cycle are perfect.

I. Metridium dianthus (Ellis) Oken.

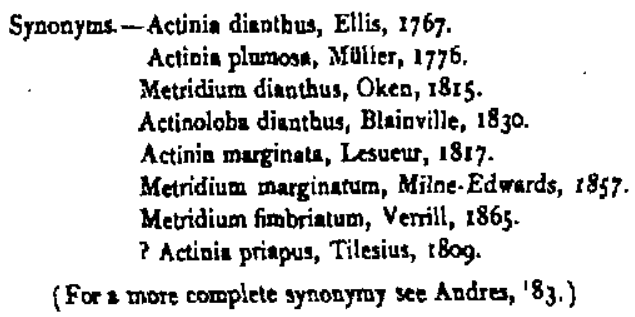

As may be seen from the above synonymy, I have united into a single species three forms which have been usually regarded as distinct, though several authors have recognized the possibility of their identity. I wish it to be understood, however, 
that in employing the specific.term dianthus, I do not desire to imply any prejudice to the claims to priority of two other terms, namely the felinum of Linnaus and the pertapetala of Pennant; I have not access at present to the works in which these terms were first used, and cannot, therefore, decide as to their validity.

Habitat.-I find in the present collection several representatives of this species, the majority of which were collected in shallow water principally from the piles of wharves or from stones, two specimens only coming from deeper water, one from 9.5 meters, where it was adherent to a deserted clam shell, and the other from 13.7 meters.

Exttrial Form.-Allowing for differences plainly due to size and degree of contraction, the external form is essentially the same in all the specimens. The base is adherent and the column is essentially cylindrical and smooth, except for, in some cases, fine longitudinal or transperse ridges, evidently due to contraction. A short distance below the margin there is a well-marked circular fold or collar, above which the wall is considerably thinner than it is below, and scattered over the surface below the collar, cinclides may be observed.

The margin is distinctly lobed and is tentaculate, the tentacles being very numerous and closely crowded in many cycles. They are rather short, and acuminate and entacmæous; I do not find, however, that the relative length and thickness of the tentacles is the same in all the specimens, differences of contraction causing them in some cases to be rather conical in shape, while in others they are much more slender and almost filiform. The disk is smooth and slightly concave, the mouth being somewhat prominent. The lips appear to be tuberculate, this appearance being due to the continuation upon them of the longitudinal ridges which occur upon the stomatodæum. In all the specimens in which the mouth is visible two gonidial grooves can be distinguished, except in one specimen in which there seemed to be only one.

Color.-Dr. Calkins' notes of the various specimens show that they can be arranged in three groups according to the prevailing color. Thus there is a group (I) in which the column 
is of a browni color, the tentacles being of the same color, while the lips are usually yellowish or orange. Dr. Calkins' description of one of the members of this group is as follows: "Light brown with long feathery tentacles of still lighter color. The extreme tips of the tentacles are white. The mouth parts are almost an olive green" and the disk is "transparent from mouth to margin."

- In a second group (II), the column is of an orange or salmon color. Four representatives of this group occur in the collection : one of these Dr. Calkins describes as being of a "bright orange " color, and the other three as being "yellowish pink."

The third group (III) has but two representatives in the collection and these are described by Dr. Calkins as being "pure white."

Size.-The specimens belonging to the brown variety are on the whole smaller than the others. Some of them are, however, considerably contracted, measuring, in this condition, 1.3-1.5 $\mathrm{cm}$. in height, the base being broadly expanded and measuring 1.8-3.5 in diameter, while at the upper part of the column the diameter is only $1.3-1.2 \mathrm{~cm}$. One specimen, which was well expanded measured $3 \mathrm{~cm}$. in height and had a diameter at about half way up the column of about $1.5 \mathrm{~cm}$., while the base measured about $2 \mathrm{~cm}$. Another specimer, also well expanded is about $4 \mathrm{~cm}$. in height and about half way up the column has a diameter of $2.3 \mathrm{~cm}$.

The specimens belonging to the orange variety have a greater average size. Three specimens measured $2.3 \mathrm{~cm} ., 1.5 \mathrm{~cm}$., and $3.5 \mathrm{~cm}$. in height, with a column diameter of $2.3 \mathrm{~cm}$., $1.3 \mathrm{~cm}$., and $2.5 \mathrm{~cm}$. respectively. Another specimen, taken at a depth of 13.7 meters, was much larger, measuring in its present condition, $12.5 \mathrm{~cm}$. in height, the base having a dianeter of 4.5 $\mathrm{cm}$. and the column about its middle measuring $3.7 \mathrm{~cm}$. in diameter. These figures do not, however, represent the original size of the specimen, since Dr. Calkins states that soon after it was placed in formalin its dimensions were "seven inches from base to mouth, five inches across the crown and three inches in diameter." 
The two white specimens are of about the same size and measure $8 \mathrm{~cm}$. in height and about $4 \mathrm{~cm}$. in diameter.

As stated above, considerable variation occurs in the length of the tentacles. Thus in a brown individual measuring $4 \mathrm{~cm}$. in height the inner tentacles measured $3.5 \mathrm{~mm}$. in length, while in another individual of the same variety, measuring only 1.3 $\mathrm{cm}$. in height, the inner tentacles were $5 \mathrm{~mm}$. long. In the large orange specimen the inner tentacles measured about $4 \mathrm{~mm}$.

Siructurt.-Considerable differences in the structural details are found in the various individuals, but these seem to be correlated, in part at least, with differences of age, that is to say of size. A comparison of the structure of the smallest individual with that of the largest would almost lead one to regard the two as distinct species; intermediate conditions, however, occur and it seems clear that the differences are growth differences associated with some tendency to variability.

The mesoglcea of the column wall has a fibrillar structure, or is even distinctly fibrous, especially in the region of the sphincter. Above the level of the collar the wall is much thinner than below, the difference being due to a difference in the thickness of the mesogloea. The circular musculature of the column is well developed and in the smaller specimens, its mesogloal processes are clearly marked of and show a tendency to branch slightly. In the larger forms, however, they are sometimes stout, with rounded extremities and may contain muscle cavities imbedded in their substance.

The sphincter is always well developed and is imbedded in the mesoglcea in the collar region. In different individuals, however, it presents decided differences in its minuter structure and I give on Pl. I three figures (Figs. 1,2 and 3) showing some of the variations observed in the present collection. In Fig. I, which is from an individual measuring $1.5 \mathrm{~cm}$, in height, the muscle cavities are more or less circular and are scattered irregularly in the mesoglcea, being separated by a narrow band from its endodermal surface. In Fig. 2, which represents only a portion of the sphincter of an individual of the white variety measuring $8 \mathrm{~cm}$. in height, the 'muscle cavities are much more 
numerous and extend quite up to the endodermal surface of the mesogloea, even the processes found on that surface containing numerous cavities. In Fig. 3, finally another arrangement is shown. The preparation from which the drawing was made was from a brown specimen which measured $3 \mathrm{~cm}$. in height, and the peculiarity which it presents lies in the band of mesogloea destitute of cavities which traverses the muscle longitudinally, dividing it into an outer and an inner portion, the latter being separated from the endodermal surface by a distinct interval as in Fig. 1. This last condition recalls the arrangement figured by Carlgren ('93) for the European $M$. dianthus and may be termed the "layered" condition.

The occurrence of a band of mesoglaea, destitute of muscle cavities, between the innes surface of the sphincters and the endoderm is probably to be regarded as leading to a layered condition of the muscle. If, in a specimen similar to that from which Fig. I was taken, the inclusion of muscle fibers within the mesoglcea were to occur again with the continued growth of the individual, an arrangement would be found similar to that seen in Fig. 3, and an alternation of periods of growth during which inciusion went on with periods in which it ceased, would result in the arrangement figured by Carlgren. It may be presumed that in the larger specimens of $M$. dianthus a layered arrangement of the sphincter will be the most frequent, but cases like that represented in Fig. 2 show that it is not an invariable arrangement for the species.

I have examined the structure of the cinclides in one specimen of the collection and find that it agrees with what Carlgren has described for the European individuals, the canais being lined by endodermal cells, so that the cinclides may be regarded as endodermal evaginations. The same is true with regard to a specimen from our eastern coast (the $M$. marginatum Auct.), and this mode of formation may probably be regarded as typical for Metridiun dianthus, though further observations are necessary to determine whether it can be regarded as characteristic of the entire subfamily.

The longitudinal musculature of the tentacles, and the radial 
musculature of the disk is ectodermal and but moderately developed. The stomatodrum is provided with well-marked longitudinal ridges, and in all the six specimens which were examined with regard to this point two siphonoglyphes were present.

In all the specimens examined, with a single exception, there were six pairs of perfect mesenteries, two of these being directives. In the majority of the specimens there were altogether five cycles of mesenteries, that is to say ninety-six pairs, but in some there were only four cycles and occasionally the fifth cycle was only imperfectly developed. In the exceptional specimen referred to above, there were only four pairs of perfect mesenteries. Two of these were directives, and between these two pairs on one side there were two pairs of perfect mesenteries, but none on the other. In other words, the irregularity affected only one-half of the specimen. In the normal half there were five cycles of mesenteries represented, the mesenteries of the fifth cycle, as is usual, lacking mesenterial filament. In the irregular half the various cycles could not be determined accurately, but judging from the relative breadths of the mesenteries the arrangement was $D$-iv-iii-iv-ii-iv-iii-iv-iii-iv$\mathrm{D}$, the mesenteries of the fifth cycle being omitted in this count.

The longitudinal muscles of the mesenteries were fairly well developed, forming a moderate thickening upon the inner portion of the primary mesenteries as represented in Fig. 4. Occasionally the pennon was somewhat narrower and more prominent, this condition being apparently normal for the directive mesenteries, the pennon in these having the form represented in Fig. 5. Parieto-basilar muscles are hardly at all developed (Fig. 4), and the basilar muscles have the form described by Carlgren, though not usually as large as those he has figured.

In only two specimens of those examined were reproductive organs present; ; in these they were borne upon the mesenteries of the second, third and fourth cycles. Acontia occurred and both the inner and outer stomata were found in the perfect mesenteries.

The specimens here described are undoubtedly identical with those described by Verrill ('65 and '69) as Metriditum fimbria- 
tum. Verrill founded this species ('65) on a specimen from San Francisco, but later ('69) gave a more complete description based on additional specimens from Puget. Sound. In both papers he states his belief that the species is closely allied to the $M$. marginatum of the Eastern Coast of America, differing from it, however, "chiefly in having longer and more slender tentacles, with the parapet further from the margin of the disk." He further suggests that $M$. marginatum, $M$. fimbriatum and $M$. dianthus "will eventually be found to belong to one very variable and widely diffused species.

Andres ('83) considers $M$. fimbriatum a synonym for $M$. marginatum, accepting Verrill's suggestion to this extent, and though retaining marginatum distinct for dianthus, states his belief that it may be identical with that form.

We have here two questions of synonomy to consider: (I) Is $M$. fimbriatum identical with $M$. marginatum? (2) Is either of these species identical with the European $M$. dianthus? To the first of these questions I would answer in the affirmative. I have carefully compared specimens of $M$. marginatum from the coast of Massachusetts (Woods Holl) with the Puget Sound specimens, and, allowing for the variability which seems to obtain even in specimens from the same locality, I see no reason for regarding the two as distinct. It may be well however to compare in some detail the specimens from the two sides of the Continent, that my conclusions in the matter may not be merely ex cathedra statements.

1. As to the coloration. It has been stated above that three principal color varieties occur in the Puget Sound specimens. The same three varieties are readily distinguishable in the Woods Holl individuals, and, in connection with this, two points of some interest may be incidentally referred to. So far as I have seen in the examination of several hundred specimens of the east coast form, the smaller individuals are always brown, the individuals of a salmon or white color being invariably large and one is tempted to suppose that the salmon and white varie--. ties are not distinct from the brown variety from the beginning, but that the brown color is characteristic of all younger individ- 
uals and is, in some cases, after the individuals have obtained a considerable size, replaced by salmon color or by white. In support of this idea it may be stated that individuals are frequently found whose color is chiefly salmon or white, but whose column is splashed with irregular bands, spots or dots of brown. This fact seems to be true also of the Puget Sound forms according to the description given by Verrill ('69). Of course all individuals do not necessarily undergo a change from the brown color with advancing age, since brown forms may frequently be found quite as large as the individuals of the other colors.

The second point to which I wish to call attention receives a simple explanation from the conclusion just stated. Salmoncolored individuals blotched with brown are not uncommon and white individuals similarly marked are also found, but, never as far as I have seen, do individuals of a salmon color blotched with white, or vice versa, occur. In other words the salmoncolored and white varieties never merge into one another while both merge into the brown variety.

2. As to dimensions the specimens which I have collected at Woods Holl agree in size fairly well with those of the present collection, except that I have never found any East Coast specimen as large as the largest Puget Sound specimen. Verrill, however, states ('64) that the more northern forms, especially those from the Bay of Fundy, are larger than those from more southerly localities.

3. As to external form 1 have not been able to distinguish any constant differences in the external form of the individuals from the two localities. The differences which Verrill considered to exist in the slendemess of the tentacles and the distance of the collar from the margin cannot be regarded as of much importance since they are apt to be due to contraction; I find indeed as much difference in both these respects between different specimens from Puget Sound or Woods Holl as between specimens from the two localities.

As to internal structure. Making due allowance for the variability in the details of the internal structure shown to exist in the Puget Sound specimens, and for the similar variability occur- 
ring in the East Coast specimens, I can see no reason for considering the two distinct. In nearly all essential peculiarities there is practical similarity, the striking differences being in the apparent absence of variation in the number of siphonoglyphes and directives in the Puget Sound specimens. This difference will, however, be discussed later.

One other point may be mentioned. $M$. marginatum has been described from the coast of New Jersey to as far north as Labrador, $M$. fimbriatum from San Francisco and Puget Sound and Dr. Calkins informs me that it also occurs at Sitka. There is no record however of its occurrence in more northerly regions, the report from the American Station of the International Polar Expedition at Point Barrow (Murdoch '85) making no mention of any species which can be considered a Metridium. If, however, the East, and West Coast species are identical it is probable that further observation will reveal their presence in the Arctic regions.

The specific identity of the East and West Coast forms being regarded as established, the question as to their identity with the European $M$. dianthus may now be considered. As pointed out above, suggestions as to their identity have been made, and, indeed, the American form has been actually identified with dianthus by some authors. Thus Couthouy (38) speaks of the occurrence in the Charles River at Boston of Actinia plumosa Müller, and Dawson ('58) describes specimens from the Gaspé basin "which appear identical with the $A$, dianthus of the British Coast."

Certainly the two forms resemble one another closely both in external form and in coloration, three of the color varieties of dianthus recognized by Gosse (60) being identical with those recognized for $M$. marginatum, while the fourth, the yellow, also occurs in the American species, but has been considered above as belonging to the salmon-colored variety. Of the internal structure of dianthus several more or less complete accounts exist, the most recent and most thorough being that of Carlgren ('93), and on comparing this point by point with what occurs in the American forms, the similarity is so great 
that there can be no doubt, I think, as to the identity of the two forms.

I have not in the above discussion considered the variability in the number of the siphonoglyphes and directives, which is so pronounced in the European and American East Coast forms, and which might be regarded as of sufficient importance to be regarded as a specific characteristic. Sufficient data are not available to determine definitely whether this variability also occurs in the American West Coast forms, but in the six specimens I examined it was not observed. But even granting that no variability in this respect occurs in the fimbriatum forms, it does not seem that this would be sufficient for considering these specifically distinct from the marginatum and dianthus forms. No one has suggested that the dianthus forms with the siphonoglyphe and one pair of directives should be separated from those with two siphonoglyphes and two pairs ofdirectives, and it would be even less reasonable, it seems to me, to separate fimbriatuil forms from marginatum or dianthus forms with two siphonoglyphes and two pairs of directives, other structural characteristics being so similar.

There are not at present sufficient data at hand for determining accurately the relative frequency of the monoglyphic condition in the European and-fimbriatum forms. To judge, however, from the statements of Thorell ('58), Gosse ('60), and Carlgren ('93), among others, the monoglyphic condition is by far the most frequent in the European specimens; the thorough observations of Parker ('97) show that it occurs in somewhat over one-half of the total number of marginalum forms which he examined; while, as stated above, it would seem to be much less frequent in the fimbriatum forms.

At the close of the list of synonyms of the species I have

( To judge from certain statements made by Gosse ('60) I should imagine that the relations of the different color varieties described above for $M$. marginatum do not hold for $\boldsymbol{M}$. dinmthus. What the physiological causes may be which produce the different ratieties is at preseot unknown, but a fact quoted by cosse is of interest in this connection. It is to the effect that on a water.logged bourd brought in by 2 trewler there were between four and five bundred specimens of $M$. diamthus, and all the individuals "un one side the board were white, all on the other opange:" 
added Activia prinpus of Tilesius. The description which Tilesius gives of this Kamtchatkian form, though given at some length and accompanied with numerous figures, leaves one in considerable doubt as to its actual affinites. The figures of the entire animal given in his PI. XIV, certainly resemble very . greatly large specimens of $M$. dianthus, especially those contained in the present collection, and I should have little hesitation in identifying with that species were it not for Fig. I, of Pl. $\mathrm{XV}$, which suggests a Thalassianthan character for the tentacles. Andres has accepted this figure as representing the true structure of the tentacies and has assigned the form to a new genus Dendractinia, placing it however among the Activiat incertae sedis. It seems to me quite probable however that the structure of the disc shown in Pl. XV, Fig. I, is not natural but has been made by dissection, the figure being of a dissected specinen. In the text (p. 407) Tilesius says that the disk " in quinque vel sex ramos, ramulos et surculos papilliferos villiferosve divisus et subdivisus est, ita, ut peripheria disci a numerosissimis tentaculorum fasciculis formetur." This might be taken as confirming the accuracy of Fig. I, but earlier in the paper (p. 396) be divides Actiniz into two groups, of which the first contains "actinias disco diviso, scilicet in ramos ramulos et surculos tentacula efformantes " and includes Actinia plumosa, Müller, Priapus polypus Forskál, Actinia effoeta Baster and Actinia priapus. The same description then which he applies to the tentacles of $A$. priapus serves also for $A$. plumosa, and this, taken in connection with the figures in Pl. XIV, seems to me to render exceedingly probable the identity of Activia priapus with Metridium dianthus. It may also be mentioned that from what we now know of the distribution of $M$. dianthus there is reaaon to expect its occurrence on Kamtchatkian shores, while, on the hand, the occurrence of a Thalassianthid is not to be expected, since, so far as at present known, such forms are essentially tropical in their distribution.

Finally I may add, that if the identification of $A$. pritipus be correct, it is possible that Brandt's $A$. farcimen (' 35 ) may also be a synonym. 


\section{Fanily CRIBRINIDE.}

Synomytus, - Bunodide. Gosse, 1858 .

Tealidx, R. Hertwig, 1882 .

Bunoductide. Verrill, $18 g 0$.

Actining with adherent base, with a strong circumscribed endodermal sphincter; usually with the column more or less verrucose and frequentiy with acrorhagi at the margin, these, however, never being ramose or frondose. Perfect mesenteries usually numerous and gonophoric. No cinclides or acontia.

I have ventured to employ a new term for the family to which Gosse originally applied the name Bunodidz. The change I have regarded as necessary on the ground that the family name should be a derivative from the name of the typical genus; my reasons for adopting Cribrina as the name for the typical genus are based upon a strict interpretation of the rules of priority and are as follows :

The family Bunodida was instituted by Gosse ('68) with the genus Bunodes (established in 1855) as its type, though previously Milne-Edwards had separated all actinians with verrucose column wall to form his group of actinines verruqueuses. Gosse took as the type of his new genus $B$. gcmmacea, a form which had long been known and has been referred by Ehrenberg in 1834, to the subgenus Cribrina. An interesting question of priority here arises. The first species mentioned by Ehrenberg under the genus Cribrina, is this very one, and following the rule, it would be taken as the type of the genus: Haddon, however, has adduced reasons ('89) for believing that Ehrenberg regarded the fith species which he included under Cribrina, namely, the Priapus polypus of Forskal, as the type, and for this reason retains Gosse's genus. The genus Bunodes certainly cannot be retained, since, as Verrill has pointed out ('99), the term had already been applied in 1854 to a genus of Eurypteroidea, and it seems better under the circumstances to consistently apply the rule and disregard Ehrenberg's possible or one might even say probable intention rather than introduce an entirely new term, such as Bunodactis, proposed by Verrill 
(99). The genus Bunodella established by Verrill ('99, p. 43) has already been withdrawn by him (99, p. 146) and need not be considered here, and the genus Evactis, also established by Verrill, is discussed later, and I need merely state here that after an examination of the type species, $E$ artemisia, Pickering, I see no reason for regarding it as distinct from Cribrina.

In 1834 Ehrenberg established a subgenus Urticina with the $A$. crassicomis of Müller as the type and later Gosse ('58) established for the same form the genus Tealia. The priority of Ehrenberg's term is generally admitted and consequently the use of Hertwig's name Tealiida for the family is inadmissible since Tealia is a nomen delendum.

I. shall have occasion later to discuss another group of generic terms namely Anthopleura Duch. \& Mich., Aulactinia Verrill, Egeon Gosse and Bunodosoma Verrill, and may state here simply my belief that they cannot be separated but must all be included under the title Anthopleura.

The genus Phymactis M. Edw. ('57) has usually been regarded as a Cribrinid (Bunodid), Haddon, I believe, being the first to suggest that it might possibly be more correctly referred to the family Aliciidx, Carlgren in a recent paper ('99) has published the result of his studies of $P$. clematis (Drayton), of which he finds Milne-Edwards' type species $P$. forida (Drayton) to be a synonym, and shows that Haddon was correct in his suggestion. I may add that I can confirm Carlgren's conclusions both as to the reference of the genus to the Aliciida and as to the synonymy of the two species mentioned, but may point out that one species, $P$. cavernata, which in the past has generally been referred to the genus Phymactis, must be removed from this genus and referred to Anthopleura. Verrill has practically already ('99) made the transfer, since he has included the species in his genus Bunodosoma.

With regard to the remaining genera which have been referred to the family little may be said, as for the most part too little is known of them to allow of certainty as to their true positions. I have already ('97) suggested the reference of Gyractis Boveri, to the Bunodidx a suggestion which has been accepted by 
Haddon. Carlgren's Isotealia ('98) must be allowed to stand for the present on account of the imperfect information in our possession concerning Hertwig's Leiotealia ('82) with which it is possibly identical, and Haddon's Ixalactis ('98) and Klunzinger's Thelactis ('77) will also stand as somewhat aberrant members of the family though it must be confessed that at present we are entirely in the dark as to the true systematic position of Thelactis as we are also to that of Physactis Verrill ('69), the last named genus being quite probably really an Aliciid, somewhat similar to Haddon's A. thadina (98). The genus Epiactis (Verrill '69) is considered further on.

Finally there remain to be considered Pseudophellia Verrill ('99), Tealiopsis Danielssen (90) and Epigonactis Verrill ('99). Danielssen refers his Tealiopsis polaris to R. Hertwig's Tealidz without however giving any definite evidence of its possessing the qualifications necessary for admission to that family; it may possess a circumscribed endodermal sphincter but neither in the text nor figures is there any indication of the existence of such a structure. If it does occur, then there seems to me a probability of Verrill's Pseudophellia being identical with Tealiopsis ; it is impossible at present to speak with certainty on this point, however. Verrill's Epigonactis was established quite recently ('98) for two species which closely resemble each other and are not a little suggestive of Urticina crassicormis from which they are distinguished however by possessing on the surface of the column depressions which serve as "brood-pouches." With regard to the systematic value of this peculiarity I am exceedingly sceptical and believe that judgment on the admissibility of the genus must be suspended until a more detailed description accompanied with figures showing the structural details has appeared.

My views as to the relationships of the various genera mentioned above may be briefly expressed thus :

Cribrina, Ehr--Synọnyms, Bunodes Gosse, Evactis Verrill, Bunodactis Verrill, Bunodella Verrill.

Urticina, Ehr.-Synonyms, Tealia Gosse, possibly Epigonactis Verrill.

Anthopleura, Duch. \& Mich.--Synonyms, Aulactinia Verrill, Egeon Gosse, Bunodosoma Verrill. 
Leiotealia, Hertwig.

Isotealia, Carlgren-possibly a synonym of Leiotealia.

Epiactis, Verrill.

Gyractis, Boveri-possibly a synonym of Cribrina.

Ixalactis, Haddon.

Pseudophellia, Verrill--possibly a synonyn of Tealiopsis.

? Tealiopsis, Danielssen.

? Thelactis, Klunzinger.

? Physactis, Verrill.

Representatives of the first three of these genera occur in the collection.

\section{Genus Cribrina Ehr.}

Cribrinidx without true acrorhagi; usually with numerous perfect mesenteries which ate in some cases arranged on other than a hexamerous plan; sphincter strong ; ectodermal musculature of the disk and tentacles not imbedded in the mesogloa;; column wall destitute of an epidermal covering and provided with verruca arranged more or less distinctly in vertical rows; tentacles simple.

Rather too much attention has been devoted in the past to the arrangement of the verrucx, in members of the Cribrinidx, whether they were arranged distinctly in vertical rows or not and whether these rows extended all the way down the column or only part of the way down. I plead guilty to such a misunderstanding of the value of the verruca in an carlier paper ('89) in which, basing my identification on this feature I described as an Aulactinia (A. stelloidcs) a form which is really a Cribrina and as a Bunodes ( $B$.tenintus) a form which is really an Anthopleura (A. granulifera).

It seems now that the presence of verrucx, without regard to their arrangement, is sufficient for the genus, distinguishing it at once from Leiotealia, Epiactis and Isotealia. The absence of true acrorhagi, characterized by a marked development of nematocysts, distinguish it from Anthopleura, while the ectodermal situation of the longitudinal muscles of the tentacles and of the radial muscles of the disc may serve as a distinction from Urticina.

ANmals N. X, ACaD. SCI, XIV, June 5, Igor-2. 
From Ixalactis and Pseudophellia it is readily separated by the simplicity of the tentacles and by the absence of an epidermal covering to the column wall.

2. Cribrina elegantissima (Brandt)

Synonymt,-Actinia ( Tarectostephenus) elegantissima, Brandt.

? Unicina crassicomis, Verrill.

The identification of the species here described with Brandt's A. eleganissima is necessarily'somewhat uncertain, since the original description is not as complete as could be wished. So far as the description goes, however, the agreement is sufficiently close to warrant the identification.

Habitat.- " A very common form on the rocks and piles" in Puget Sound. (Calkins.)

External form,- The base is circular and adherent. The column is almost cylindrical (Figs. 7 and 8) and in its upper part is provided with vertical rows of verrucx, which become obsolete towards the base. Some of the rows extend much farther down the column than others, and according to their length, about four sets can be distinguished, of which the third and fourth sets are much shorter than the other two. The lower part of the column is ridged transversely probably as the result of contraction. A well-defined margin is present, and a distinct interval exists between it and the bases of the outermost tentacles.

These are short, rather blunt at the apex and all finely ridged longitudinally. They appear to be arranged in about five cycles, though their total number does not agree with what would be expected from such an arrangement; as will be seen later there are irregularities in the arrangement of the mesenteries which probably explain the irregularities of the tentacles. The disk is marked by fine radiating furrows and is slightly concave, the peristome being prominent. In two of the specimens the stomatodrum is somewhat evaginated and it can be seen that its walls are longitudinally ridged. Two siphonoglyphes seem to be present as a rule, though sometimes irregular in position, and in one individual there were three, and in another only one. 
Color.-The specimens when I received them were in formalin and showed a distinct green coloration in the upper part of the column, while the lower part was a dingy white. On transferring them to alcohol the green coloration gradually disappeared, the pigment to which it was due being evidently soluble in that medium. In life the coloration, according to Dr. Calkins' description, was quite brilliant. He says, "The ground color is bright green while rows of bright red vary it. Each tentacle is colored in the niddle by a ring of brown and the tip is of the same color. They are very gorgeous" (Fig. 8).

Brandt's description of the coloration of his $A$. digantissima is as follows: "Red, green, blue or fuscous, or even green spotted with purple. Disc olivaceous, striated with white. Tentacles white, purple at the tips and marked at the middle by a purple band." Comparing this with Dr. Calkins' description a decided similarity is noticeable, Brandt's account, however, indicating considerable variation in the color of the column. The markings of the tentacles Calkins describes as brown, while Brandt states that they are purple, a discrcpancy perhaps due to variation, or perhaps to the uncertain way in which the term purple is frequently used. In both descriptions the arrangement of the markings is identical.

Size.-The three specimens sent me were all apparently snall, measuring $3,1.8$ and $2.5 \mathrm{~cm}$. in height, and 3,3 , and $1.5 \mathrm{~cm}$. in breadth, respectively. Dr. Calkins in his notes says that some individuals "are of large size, five or six inches long and three or four in diameter, and Brandt's statement regarding the size is "Corpus magnum." The inner tentacles have a length of about $0.4-0.5 \mathrm{~cm}$, while the outer ones seem to be slightly longer.

Structure-The verrucx are hollow outpouchings of the column wall (Pig. 9). The circular musculature of the column is well developed in the intervals between the verrucx and is supported upon branched mesogloal processes, which are frequently grouped together in bunches arising from a common base. The walls of the verrucal outpouchings are, however, almost destitute of musculature, except at the very 
summit of the pouch. Here a small number of muscle processes may be seen projecting from the inner surface of the mesoglea, which is here slightly thickened. The ectoderm over the summits of the verrucæ is similar to that described for the verruca of Coreus pedunculatus by von Heider ("77) and for those of Phymanthus crucifur by myself ('89), the layer of cells at the base of the epithelium in the latter form being also present here. Indeed, the only difference between the structure of the verrucx of the present species and those of Phymanthus is the existence of a special musculature on the endodermal surface of the summits of the papilla in the former.

The sphincter, which occurs below the fosse intervening between the margin and the bases of the outermost tentacles, is of the circumscribed pedunculate bipinnate variety' (Fig. 10), and is strong. The ectodermal musculature of the disc is well developed, the processes of mesogloca which support it anastomosing somewhat to form a reticulum, a condition internediate between the typical ectodermal and the mesoglceal arrangements being thus produced (Fig. 11). Transwerse sections of the tentacles show that their ectodermal musculature is also well developed, but no anastomoses of the mesogloeal processes occur (Fig. 12).

The walls of the stomatodzum are thrown into well-marked longitudinal ridges and are richly supplied with glands, except

1 It seems adrisable that certain terms should be egreed upon for the description of the principal varieties of endodermal and mesoglosal sphincters. So far as" the endodermal are concerned, the terms "diffuse" and "circumscribed," already in general use, serve' to divide them into two groups; but a further subdivision of the circumscribed forms would be useful. I would suggest as a first subdivision that those which arise by $a$ number of main branches from the columin mesogloca, as in Afyonanthus ambiguns and Oulactis californien for erample, be grouped as "sessile," while those which have a distinct peduncle be termed "peduneulate." The latter group may again be divided, according as the lamelix radiate from a ceatral mass or ate inserted into an exial larsella, into "palmate " and "pinnate" varieties. Such a classification may be represented in tabular form, thus :

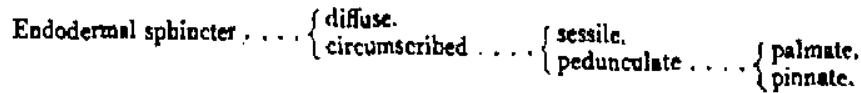

Such a classification is of course merely tentutive and presunably imperfect, but it may serve to some extent to obviate the long description now necessary. 
in the regions of the siphonoglyphes. That irregularities occur the arrangement of the latter structures has already been noted. In one of the three specimens which I sectioned I found three siphonoglyphes, while in the second individual though only two were present they were not opposite one another, thirty-seven pairs of mesenteries intervening between the two on one side while on the other side there were fifty-five pairs. In the third specimen but a single siphonoglyphe occurred.

In connection with the siphonoglyphe a peculiarity of structure exists. The endoderm over the general surface of the stomatodxum is comparatively low and inconspicuous, but in the region of the siphonoglyphes it suddenly becomes very high and retains this condition over the entire surface of the grooves (Fig. 12). I speak of the endoderm being thickened, but the appearance is rather as if the endodermal surface of the mesoglcea were drawn out into exceedingly fine fibrillx which anastomose with one another to form a reticulum with elongated meshes, the endodermal cells being arranged on the terminal part of the fibrillæ. The appearance presented is very similar to that which I have described as occurring in the mesenteries of Cerianthus americanus ('90).

The individual with three siphonoglyphes had three pairs of directives, while the one with two siphonoglyphes had correspondingly two pairs unequally spaced, and the third specimen with one siphonoglyphe had but a single pair. As might be expected from the arrangement of the directives considerable irregularity occurred in the mesenteries. In the upper part of the column each alternate pair seemed to be perfect as a rule, but lower down seven imperfect pairs intervened in certain sectors between successive perfect ones. It may be supposed from this that there were typically four cycles of mesenteries, three of which were perfect and one imperfect. The typical arrangement occurred however only in a few sectors; examples of a fith incomplete cycle occurred here and there and in addition both imperfect and perfect pairs were not infrequently intercalated so that it was impossible to determine even whether the arrangement was hexamerous or not, although it may be supposed that in one specimen at 
least it was decamerous. To illustrate the irregularity which exists, Iig. 1, representing the arrangement of the mesenteries in the specimen with two siphonoglyplies a little below the middle of the stomatodæum, is appended.

Attention may be called to one interesting irregularity in this specimen, and that is the development of two pairs of mesenteries in the endoccel of one of the perfect pairs.

The longitudinal musculature of the perfect mesenteries is fairly well developed (Fig. 14) and there is a well-marked parieto-

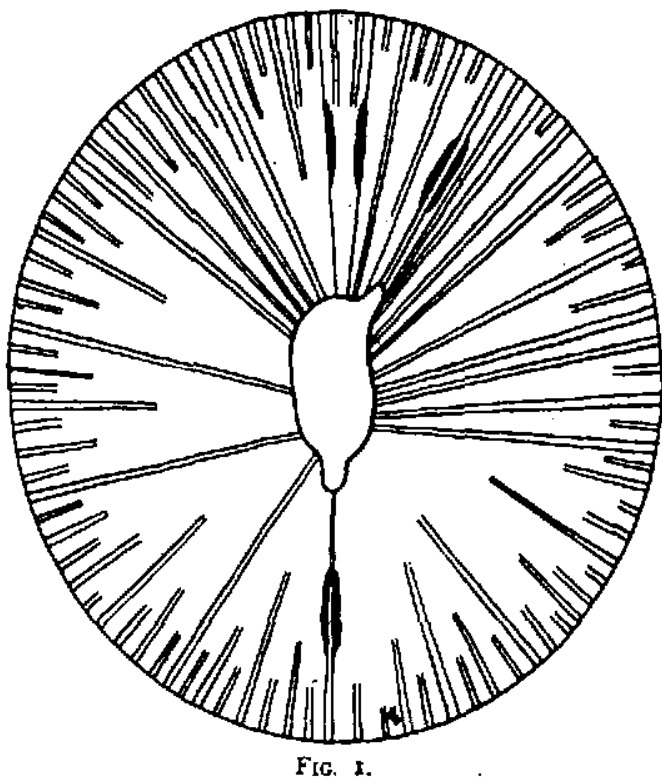

basilar forming a fold upon the peripheral portion of each mesentery. Both inner and outer mesenterial stomata are present. Reproductive organs may apparently be developed on any of the mesenteries, with the exception of the directives and of the incomplete cycle, but in the two specimens examined minutely with this point in view they are not distributed with perfect regularity, some mesenteries of every cycle lacking them.

There is no doubt but that in many respects of structure this form approaches closely to Urticino crassicornis, the differences 
in the arrangement of the ectodermal musculature of the disk and tentacles and in the form of the sphincter being possibly explicable on the assumption that the specimens examined by me were all young. I have not had the opportunity of comparing any of the large specimens of this species with fully grown urticinas, but it would seem that the irregularities in the siphonoglyphes which occurred in all of the three specimens examined indicate the distinctness of the species, since such irregularities have not been found to occur in Urticina.

\section{Cribrina artimisia (Pickering)}

Synonym:-Actinia artemisia, Pickering in Dana.

Cereus artemisia, Milne-Edwards.

Evactis artemisia, Verrill.

Habitat.-The individuals of this species were found at Discovery Bay, the same locality from which they were originally described by Dana ('46). They live buried in the sand, the disk being flush with the surface in expansion, and are attached below to valves of shells or more rarely to stones.

External Forms.-The base is adherent and the column in contraction is club-shaped (Fig. 25). A short distance above the limbus the column suddenly contracts and then gradually enlarges again until above it may equal or exceed the base in diameter. In all three specimens which I had for examination the tentacles and disk were completely hidden and the upper extremity of the column presented an almost flat surface, slightly depressed towards the center. The appearance presented by these specimens little resembles accordingly the figure given by Dana, but it must be remembered that this figure is of an expanded individual. Dana describes the column as being enlarged at its middle and contracted more or less above and below. It is probable that in the preserved specimens the upper contracted portion is completely involuted, and the enlarged extremity corresponds to the middle enlargement of the expanded form.

The column in its lower part is horizontally rugose, evidently as the result of contraction, and is provided with a 
number of rather low tubercles arranged in about twelve longitudinal rows, the individual tubercles of each row being separated by considerable intervals. Higher up, where the column begins to enlarge, the rows are more numerous, and at the upper part, the tubercles become decidedly papilliform. They are arranged in about $s 6$ rows and have particles of sand and shell adhering to them, their verrucal nature being thus demonstrated.

By dividing the column longitudinally, it became evident that there were no acrorhagi, the papilla of the margin being the uppermost verruca of the longitudinal rows.

The number of the tentacles could not be determined with certainty. They were simple, rather short and acuminate, and, as Dana has stated, are ectacmaous. The disk. and mouth were hidden in all the specimens.

Color.-The coloration as stated in Dr. Calkins' notes differs a little for that described by Dana. It was "greenish-yellow" at the upper portion of the column and ". yellowish-white "lower down, while the tentacles are stated to have " scarlet or purplish tips." According to Dana, who quotes a description by Drayton "the general color of the exterior of the body is a yellowish. green. The tubercles have a dark sap-green color; they become obsolete below, yet the green line continues to the base of the animal. The colors of the tentacles are various and shaded like those of the prism; the disk is dull greenish, becoming darker towards the base of the tentacles, and the mouth is feshcolored."

Size.-In the preserved specimens the base measured $2.5 \mathrm{~cm}$. in diameter. The column a short distance above the limbus, at its narrowest point, measured $\mathrm{I} \mathrm{cm}$. in diameter, but above it equalled the diameter of the base or even reached a diameter of $2.8 \mathrm{~cm}$. The height of the column was about $6.0 \mathrm{~cm}$.

The inner tentacles were about $0.5 \mathrm{~cm}$. in length, while the outer ones measured $0.65-0.7 \mathrm{~cm}$. For the expanded animal, Dana gives the greatest diameters of the column as about $5.5 \mathrm{~cm}$. ( $2 \%$ inches), while the outer tentacies he states to have been $2.5 \mathrm{~cm}$. ( $\mathrm{I}$ inch) in length and the inner ones $1.25 \mathrm{~cm}$. (1/2 inch). 
Internal Siructure.-The mesogloa of the column wall is, relatively to the size of the individuals, rather thin and is provided with a well-developed circular musculature, whose general appearance resembles that of $C$. elegantissima. In the upper part of the column, however, it is comparatively poorly developed, and also on the inner walls of the evaginations which produce the verrucæ, being entirely wanting at the apex of these.

The sphincter (7ig. 18) is large and is of the pedunculate bipinnate type, the lateral lamella of one side being, however, stronger than those of the other so that it is properly described as unequally bipinnate. In one of the three specimens a deep incisure occurred on one side of the sphincter, reaching almost to the median axis and giving the section of the sphincter a reniform outline. This was wanting, however, in the other two in which the sphincters were oval in section.

The tentacles are not ridged and have a well-developed, though simple, ectodermal musculature. Their endoderm, as well as that of the disk and of the upper part of the column wall, is richly laden with granules of black pigment, insoluble in the reagents employed in hardening and sectioning. The ectodermal musculature of the disk ( $\boldsymbol{F i g}$. 18) resembles that of the tentacles, being supported on well-developed simple or but slightly branched processes of mesogloea.

Two siphonoglyphes are present and the walls of the stomatodxum are longitudinally ridged and in addition considerably folded.

The mesenteries are arranged in four cycles and there are in all forty-eight pairs $(6,6,12,24)$. In sections through the upper part of the columu all but those of the fourth cycle are seen to be perfect, but below the level of the stomatodaum the various cycles can be distinguished by the relative breadths of the various pairs, those of the first and second cycles being however nearly similar in this respect. The mesenteries of the fourth cycle do not bear mesenterial flaments and there are two pairs of directives, placed symmetrically.

The longitudinal musculature is well developed (Fig. 19), covering almost half of the non-gonophoric portion of the 
mesenteries and ending somewhat abruptly at either edge. At the outer edge a mesogloeal process, stronger than usual, is developed and from it a number of mesogloeal processes arise. The paricto-basilar muscles form a distinct fold on the lower portions of the mesenteries, and the basilar is fairly well developed, having the appearance shown in Pl. III, Fig. 20.

Both the inner and outer mesenterial stomata are present, and all the mesenteries, with the exception of those of the fourth cycle and the directives, bear reproductive organs.

From the examination of this species it has seemed to me impossible to separate it from the genus Cribrina. Verrill ('69) has established for its reception the genus Evactis characterized by possessing pores in the column wall as well as verruce and by the tentacles being ectacmæous. I have not been able in sections to discover any distinct pores in the column wall and am inclined to believe that the emission of jets of water "as from a watering pot" which has been observed, was through minute ruptures of the wall, the mesogloea being comparatively thin especially in the upper part of the column. If this be correct, little importance can be attributed to their power of ejecting water. The tentacles of C. artemisia are, indeed, ectacmxous but in every other respect the form has the typical structural characteristies of a Cribrina, and it seems advisable to regard the ectacmzous arrangement of the tentacles as a specific rather than as a generic peculiarity.

\section{Genus URTiciNa Ehrenberg.}

Cribrinide without true acrorhagi; with numerous perfect mesenteries frequently arranged decamerously; sphincter strong ; ectodermal musculature of the disk and tentacles imbedded in the mesogloea; column wall destitute of an epidermal covering, and usually provided with verrucæ arranged more or less definitely in vertical series; tentacles simple.

The synonymy of this genus has been recorded by Andres ('83) and more recently by Carlgren ('93). As at present understood it includes but a single species, $A$. crassicarnis, a fact 
which renders the establishment of a final definition exceedingly uncertain.

The name Urticina was originally applied by Ehrenberg (34) to a subdivision of his subgenus Actinia Isacrnaa, and included numerous forms now assigned to other genera. It was not until much later that the genus became at all definitely limited and then it was under the name Tealia, proposed by Gosse in 1858 . The essential peculiarity of the genus according to the definition given by Gosse, was that the verrucze were scattered irregularly over the column wall and were not arranged in vertical series, and this supposed characteristic was generally accepted by succeeding authors. Messrs. G. Y. and A. F. Dixon ('89) pointed out that this peculiarity does not really exist, the verruca being really in vertical series, though the regularity of the arrangement is not always readily perceivable, and Carlgren (93) has called attention to the same fact. The original distinguishing peculiarity which separated the genus from Cribrina being thus disposed of, both the Dixons and Carlgren found a new distinction in the decamerous arrangement of the mesenteries, the former authors, indeed, going 50 far as to suggest that this peculiarity was worthy of being raised to the dignity of a family characteristic.

To establish a genus on its decamerism seems to me, in view of what we now know concerning departures from hexamerism in the Hexactinix, to place it on an exceedingly insecure foundation. And that this is true in the present case has been recently shown by Verrill ('99, p. 216 , note) who states that he found " many specimens [ of Urticina crassicornis] hexamerous both as to tentacles and mesenteries; many others decamerous; some octamerous; and a few irregular or unequally developed on opposite sides." A careful study of the mesenteries of the individuals contained in the present collection reveals in no case a perfect decamerism, but an irregular arrangement which appears, however, to be based on a decamerism. Consequently we may, I believe, hold the character of decamerism to be insufficient for the characterization of the genus, and if it is to be maintained distinct from Cribrina, we must seek for other peculiarities. 
As the definition I have given above suggests, such a distinction may possibly be found in the enclosure of the longitudinal musculature of the tentacles and the radial musculature of the disk in the mesoglcea, an arrangement which seems to be absent in typical Cribrinas. It must be remembered, however, that as in the case of $C$. elegantissimus described above, transitional conditions between what is found in Urticina and in typical Cribrinas occur, and the absolute value of such a characteristic is accordingly open to question. Personally I am somewhat inclined to regard the distinctness of Urticina from Cribrina as not proven, but prefer to await the discovery either of additional species clearly belonging to the former genus or of transitional forms which will clearly bridge over such differences as may appear to exist between the two.

\section{Urticina crassicornis (Müller) Ehr.}

[For the synonymy of this species vide Andres ('83) and Carlgren ('93).]

Several specimens of this form, which has previously been described for the West Coast by Verrill (69), occur in the collection and show considerable variation in their external characters.

Habitat.-The majority of the specimens were found attached to stones under wharves and accordingly in shallow water. Two, however, were found imbedded in sand to a depth of six inches or a foot, being attached below to stones. This habit does not seem to be a usual one for the species but Dicquemare ('73) has described it for individuals obtained by him at Havre, and Teale ('37) speaks of individuals being partly buried in sand on the coast of Yorkshire.

External Form.-It does not seem necessary to give a detailed description of this well-known form, but mention should be made of certain peculiarities presented by the various specimens. And first as regards the verrucz. These in all the specimens were distinctly in vertical series, but their distribution varied somewhat. In some specimens they were large and 
somewhat irregular in shape and were distributed over the entire surface of the column, those towards both the margin and the limbus being, however, smaller than those situated in the intervening region. In others again they became obsolete above, occurring on only the lower two-thirds or three-quarters of the column and in one specimen they occurred only on the lower half of the body, those at the limbus in this case being relatively very small, while those above were larger, about I $\mathrm{mm}$. in diameter, but were more scattered, that is to say were separated from one another by larger incervals than usual. In the arenicolous specimens again the verruca were limited to the upper third of the column, not extending upwards, however, quite as far as the margin, and the lower portion of the body presented no signs of them, except very faint indications immediately above the limbus. A further peculiarity of these forms was that numerous particles of sand and shell were adherent to the verrucose region of the column, a condition not presented by any other specimens in the collections.

I have not access at present to all the literature dealing with this species, but it seems evident that there is considerable variation in the distribution, size and number of the verruca in different individuals. As regards their distribution the verrucx may present the various conditions described above, or may be. apparently entirely absent. To a certain extent at least these variations as seen in preserved specimens may be due to the retractibility of the verrucx, which, to quote the statement of Teale ('37) "admit of retractibility to such a degree as to render the corium perfectly smooth, so that the small opaque spot alone indicates their former situation; they also can be protruded to nearly a line in length, when they bear a close resemblance to rudimentary tentacula. The eminences on one side are often seen in the utmost degree of protrusion, whilst, on the other, they are scarcely perceptible." In some of the present specimens, "the small opaque spots" mentioned by Teale and due to the peculiar structure of the epithelium of the summits of the verruca, could be perceived on those portions of the column which appeared to be destitute of verruca, but this was not the 
case in the arenicolous individuals. The extent of the protrusion of the verrucæ together with the amount of contraction of the column would bring about variations in the proximity of the verruca, which are frequently described as being separated from one another, though in the present specimens they are so closely approximated as to be in some cases more or less quadrangular in outline, owing to mutual contact. So too the amount of protrusion will produce variations in their size; in all the specimens of the present collection the verrucx about the middle of the column are larger than those above and below, but in the different individuals the size of the largest ones vary, being as much as over I $\mathrm{mm}$. in diameter in some specimens, while in others they are less than half that size.

I have discussed these varieties of the verruca somewhat at length because they scrve to illustrate very pointedly the uncertainty of taking external peculiarities alone as a basis for specific distinctions. When I first examined the specimens of the present collection I regarded the arenicolous forms as quite distinct from the others and it was only after I had studied the internal structure of both that I became certain of their identity.

One other point in the external structure I may refer to briefly namely, the arrangement of the tentacles, The decamerism is fairly well pronounced, but never perfect: thus in one specimen is which an accurate count was made there were 133 tentacles only, instead of the 160 which might be expected. The variations of the tentacles however being associated with the arrangement of the mesenteries, need not be discussed in detail and I mention it merely on account of the insportance which has been assigned to it by Cunningham ('89).

Color-All the specimens collected were uniform in color throughout the column, and were either red or orange brown (the "color of an over ripe banana " Calkins). The arenicolous forms were of a bright vernilion color, with paler tentacles, and their appearance when dug from the sand has been so graphically described by Dr. Calkins that I quote his description. "They look very much like a tomato baked in bread crumbs. They have the same wrinkled appearance or the skin, while the ap- 
pearan:c of the bread crumbs is given by the numerous small pieces of shell attached to the upper end." 1 The tentacles in some of the specimens at least were banded with color. Although none of the specimens showed any traces of green in their coloration, yet such varieties have been described from the West Coast. Verrill ('69) has described them, and one of the drawings of Mr. Agassiz is evidently of an individual of this species in which the color of the coluinn is grass green irregularly blotched with deep red, the tentacles being pinkish, with a dark red band a short distance above the base. The drawing shows no indication of warts in the lower portion of the column; whether or not they" were present on the upper part cannot be determined since it is hidden by the tentacles.

Size.-All the specimens were of a goodly size, the smallest measuring about $4.5 \mathrm{~cm}$. in height and diameter while the largest was $7.5 \mathrm{~cm}$. in height and $5.5 \mathrm{~cm}$. in diameter, Dr. Calkins describes one of the specimens as having in life a height of $7.5 \mathrm{~cm}$. and a diameter of $5.0 \mathrm{~cm}$. while another he describes as reaching a height of $12.5 \mathrm{~cm}$.

Internal Structurt:-I have found some variation in the form of the sphincter in the Puget Sound specimens. Its general appearance in the majority of the individuals examined resembles closely the condition figured by the Hertivigs ('79), that is to say, the mesoglceal lamella radiate out for a central mass of mesoglcea, sometimes more or less homogeneous in appearance, sometimes showing more or less clearly its origin by fusion of the basal portions of the lamella. In all my preparations, however, the lamella are much more numerous and much more delicate than figured by the Hertivigs, a condition also noted by Carlgren ('93) in the specimens examined by hirn. It may be noticed that at one point in the periphery of the specimen figured by the

\footnotetext{
I Since writing the above lines I have received from Professor Yerrill drawings of a specimen tak. $n$ at Port Townsend in 30 fathons wbich is evidentiy the same as the arenicolons variety of litticinn crs sicomis described qbove. The drawing represents the column as being of a bright scarlet color, with very mumerous and distinctly marked vernce of a yellowish color in its upper part and with long, rather stout tentecles of a yellowish or buff color without bands but with a certain amount of red at the base.
} 
Hertwigs there is a deep incisure, extending almost to the central core of mesoglœa; I found a similar incision, somewhat more extensive indeed, in one specimen I examined, but in others it was entirely wanting. Carlgren ('93) states that in the individuals he examined the arrangement of the lamella differed from what the Hertwigs describe in being attached at their bases to an axial lamella instead of a solid core; that is, he finds the sphincter is bipinnate instead of palmate as the Hertwigs describe it. In a single specimen of those I examined I found a typically bipinnate sphincter a figure of which is given on Pl. I. (Fig. 6). It seems accordingly that we may find in individuals of Tealia crassicorsis, either palmate or pinnate sphincters, the latter probably representing what may be considered a persistence of an embryonic condition from which the palmate is derived by a fusion of the basal portions of the lateral lamellx.

As to the arrangement of the musculature of the mesenteries and of the tentacles and disk I find nothing to add to the descriptions given by Carlgren.

It is well known that the mesenteries of $U$. crassicornis are arranged more or less perfectly on a decamerous plan. In none of the specimens I have examined, however, is the total number of mesenteries an exact multiple of ten; thus in one specimen there were altogether $8 \mathrm{i}$ pairs of mesenteries, in another 91 , and in another 104. The variation from the typical number depends on irregularities in the development of the younger series of mesenteries. Thus in the three specimens just referred to the first three cycles were regularly decamerous, their formula being $10,10,20$, but considerable irregularity occurred in the succeeding cycles. Thus in the specimen with a total of $8 \mathrm{I}$ pairs the fourth cycle was completely developed except that in a primary interspace on one side of one of the directive pairs there were only two representatives of it instead of foir, the two pairs which were lacking being those nearest the pair of directives. To compensate for this diminution in the total number, in another primary interspace there were two accessory pairs of mesenteries which may be regarded as representatives of a fifth cycle, and in still another interspace there 
was a single additional pair of this fifth cycle. In the individual with a total of 91 pairs irregularities occurred in only two of the primary interspaces. The fourth cycle was completely developed so that there were $10,10,20,40=80$ pairs of regular mesenteries; and in addition I I pairs representing a fifth cycle. Eight of these were situated in a primary interspace next one of the directive pairs and alternated in a regular manner with

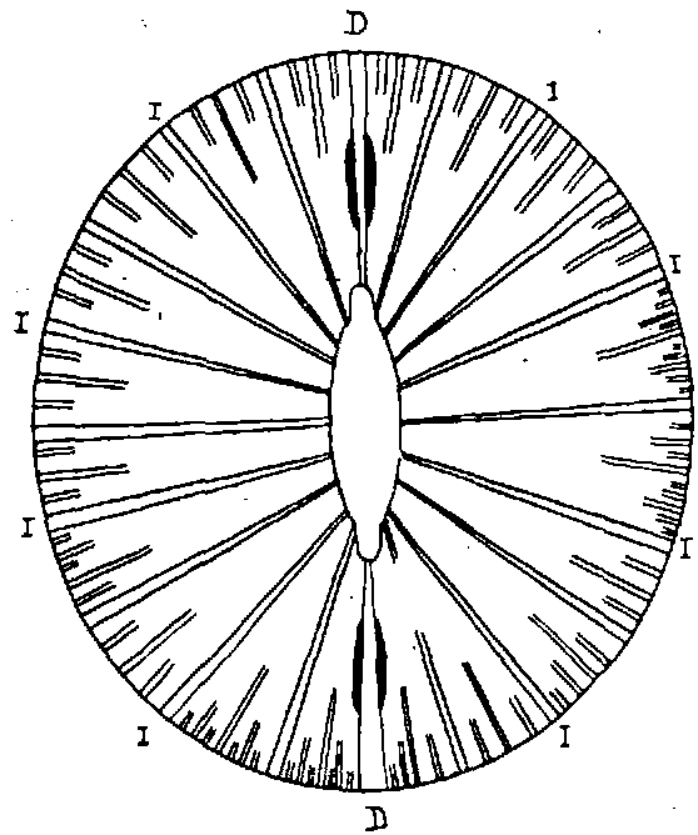

Frg. II.

the pairs of the older cycles; the other three occurred in the middle lateral interspace of the other side of the body, one of them intervening between the primary mesenteries on one side of the interspace and the succeeding member of the fourth cycle, while the other two alternated with the fourth cycle pair next the primary pair on the other side of the interspace. Finally in the individual with 104 pairs thcre are again four cycles regularly developed; in a primary interspace next one of the

Anvars N. Y. ACaD. Scr., XIV, June 5, I90I-3. 
directive pairs there are 8 pairs of a fifth cycle regularly arranged and in the interspace lateral to this there are two pairs of the fifth cycle. In each the two interspaces on the other side of the same directives there is a single pair of the fifth cycle, and in the middle lateral interspace of this same side of the body there are 8 pairs of the fith cycle and in addition 6 representatives of a sixth cycle. The arrangement in this specimen is shown in the annexed figure, from which it may be seen that Carlgren's law that the mesenteries of the last cycle develop earliest in the interspaces adjoining the oldest pairs already present, is complied with.

The mesenteries of the first cycle are complete throughout the entire length of the stomatodxum; those of the second cycle are also complete, but are not attached so far down the stomatodxum as the members of the first cycle, while those of the third cycle reach the stomatodæum only in its uppermost part. The fourth, fifth and sixth cycles are incomplete. All the members of the first two cycles are sterile, the reproductive organs being borne apparently by the members of the third and fourth cycles. Both oral and marginal mesenterial stomata are present, the latter usually quite small.

Finally a word as to the synonymy of the West Coast specimens of $U$. crassicornis. As already stated, Verrill ('69) was the first to correctly identify this species from the West Coast of America, and he records its occurrence in Puget Sound, and in the Arctic Ocean north of Behring Straits, while Murdoch ('85), found it at Point Barrow. Verrill in his list of synonyms includes, with some doubt however, the $A$. Laurentii and the A. elegantissima of Brandt (35) obtained in Behring Sea and at Sitka; Andres regards these two forms as being species delenda on account of the insufficiency of their descriptions. I believe, however, that there are sufficient grounds for identifying the $A$. Laurentii with $U$. crassicornis, though I think Verrill was probably in error in likewise identifying the $A$. elegantissima with that species, since I have found in the present collection forms, described in preceding pages, which seem to agree with Brandt's description. I may say that I made an 
endeavor to ascertain if any of the specimens collected by Mertens were still in existence, but the endeavor proved futile.

Genus Anthopleura, Duch, \& Mich.

In 1860 Duchassaing \& Michelotti established the genus Anthopleura for a Cribrinid characterized by possessing verruca arranged in longitudinal rows and with tentaculiform acrorhagi. In a later paper ('64) they added to the original single species, $A$. Krebsi upon which the genus was founded, other forms, one of which at least possessed lobed acrorhagi, altering at the same time the definition of the genus so that it became rather indefinite. In 1864 Verrill established a genus Aulactinia for a Cribrinid also possessing verruca arranged in longitudinal rows though becoming obsolete below and having prominent acrorhagi which were distinctly lobed. The later action of Duchassaing and Michelotti in including in their genus a form with lobed verrucx led Verrill in 1869 to suggest the possibility of the identity of the two genera, but Andres ('83), going back to first principles, recognizes both, placing the forms with simple acrorhagi in the genus Anthopleura, while those in which they are distinctly lobed he refers to Aulactinia. Verrill in his most recent papers ('99) considers the two genera distinct and adds a third Bunodosoma to which he refers the $A$. granulifera of Lesueur and his Bunodes cascruata, and which he characterizes by possessing lobulated acrorhagi and verrucze which are not adhesive.

It does not seem to me that the simplicity or lobulation of the acrorhagi is a feature worthy of generic importance when we find as much general similarity in such forms as Aulactinio capitata, Anthopleura granulifera and Bunodosoma cavernata, all of which forms I have had the opportunity of studying. As to whether the adhesiveness of the verruca may prove to be a feature of generic importance, I feel more uncertain, but at present am inclined to deny it that value.

The genus Ageon described by Gosse ('65) seems to be undoubtedly identical with Aulactinia and need not be discussed.

I would then define the genus Anthopleura as follows : 
Genus Anthopleura Duch. \& Mich.

$$
\begin{aligned}
& \text { Synonyms.-Aulactipia, Verrill, } 1864 . \\
& \text { Ageon, Gosse, } 1865 . \\
& \text { Bubodosom, Verrill, I\$gg. }
\end{aligned}
$$

Cribrinide with true acrorhagi, usually with numerous perfect mesenteries, sphincter strong, column destitute of an epidermal covering and provided with verrucx arranged more or less definitely in vertical series, tentacies simple.

\section{Anthopleura xanthogrammica (Brandt)}

Synonym. - Actinis (Teractostephanus), xanthogrammica, Brandt, 1835.

This species was found in only one locality, under the slaughter house at Port Townsend, but it occurred there in large numbers. An excellent figure of it is among the drawings kindly lent me by Mr. Agassiz, the individual figured having been obtained at San Francisco. Dr. Calkins states that evidences of multiplication by fission were not unfrequent among the Port Townsend specimens.

Extermal Form.-The base is adherent. The column (Pl. II, Fig. 17) is provided with rows of tuberculiform verruca, to which particles of sand and small stones adhere and which are arranged in distinct vertical rows extending to the limbus as a rule, though in the upper part of the column shorter rows alternate with the longer ones. The margin is separated by a distinct though shallow fosse from the bases of the outermost tentacles, and from the margin of the outer wall of the fosse there project blunt processes, one of which corresponds to the summit of each row of verruce (Fig. 19, $a, c$ ). These are undoubtedly acrorhagi. They are much more distinct in some of the preserved individuals than in others and, indeed, may be more prominent at one portion of the margin than at another in the same individual, here appearing as mere hemispherical clevations and there as distinct blunt tentaculiform projections, or again having a distinctly lobed form.

The tentacles in the preserved specimens are very moderate in length, conical and rather obtusely pointed. In Mr. Agassiz's drawing they are represented however as rather long and slender, 
while in that by Dr. Calkins they agree more with the condition in the preserved specimens. They are quite smooth and are arranged in about four cycles and are fairly numerous, though I did not succeed in making an accurate enumeration of them. The disk is smooth and somewhat concave and the peristome slightly elevated. The lips are ridged and there are two rather feebly marked gonidial grooves in the specimens examined.

Color.-Dr. Calkins describes the individuals obtained by him as being "crystalline" in appearance with "pink-tipped tentacles." The drawing which accompanied his notes (Iig. 17) shows the coiumn, disk and bases of the tentacles to be faintly greenish-yellow, the tips of the tentacles being the only brightly colored portions of the animal. Mr. Agassiz's drawing, which is undoubtedly of the same species, represents the column as being of a bright green color, the disk of a dark olive green; this color extending upon the bases of the tentacles, being there succeeded by a yellow band, beyond which the tentacles are of a bright pink.

Size.-The preserved specimens sent me measured 1.0-1.5 $\mathrm{cm}$. in height and about the same in diameter. Dr. Calkins states that the largest individuals "when expanded, measured fully three inches across the crown, but the average was much less."

Stricture.-A longitudinal section of the column wall resembles closely what I have described and figured for Cribrina elegantissima. The tubercles differ from those of Cribrina only in the absence of a special development of endodermal musclesat their summits and in the presence of a distinct though fine band of nerve fibers in the basal portion of the modified ectoderm.

The sphincter is situated upon the foor of the fosse, just internal to the acrorhagi. It is oval in section and is of the pedunculate palmate variety (Fig. 22). The ectoderm of the acrorhagi is abundantly supplied with nenratocysts, whereby they can readily be distinguished from tentacles in section. In these latter the longitudinal musculature is not imbedded in the mesoglca and resembles in appearance that of C. cligantissima, as does also the radiating musculature of the disk, though here the 
reticular arrangement of the mesoglceal processes cannot be distinguished as clearly as in that form.

The stomatodæum is longitudinally ridged and in the specimens examined was provided with two siphonoglyphes, which have the same structure as those of $C$. elegantissima.

The arrangement of the mesenteries is somewhat irregular. Apparently an hexamerous arrangement is the basis, the primaries, secondaries and tertiary cycles being perfect, the last to a less extent than the others. A fourth cycle is also present and is complete, but there are in addition representatives of a fifth and even of a sixth cycle irregularly distributed, a disturbance of the symmetry being thus produced.

Both the outer and inner stomata are present. The longitudinal musculature is well developed and in sections of the perfect mesenteries about half way down the column terminates at its outer edge in a strong process from which lateral lamella arise (Fig. 23). Lower down this arrangement is not apparent, the muscle processes diminishing in size toward each edge of the muscle area. The parieto-basilar (Fis. 24) is well developed, forming a marked fold. The basilar muscle (7ig. 25) is faitly well developed, resembling somewhat that of $C$. artemisia, though smaller in accordance with the smaller size of the specimens. The tertiary mesenteries are all fertile, and, in addition, reproductive organs occur on some of the mesenteries of the fourth cycle.

The identification of this species with Brandt's Actinio xanthogrammica is suggested in the memoranda accompanying Mr. Agassiz' drawing, and though Brandt makes no mention of the conspicuously pink-tipped tentacles yet it is quite possible, indeed probable, that this is the proper identification, as it is evident that the coloration of the species may vary considerably.

I was for a-time inclined to identify it with Verrill's Anthopleura Dowii, but hesitate to do so on account of the geographical distribution of that form and the absence of data as to its internal structure. It is evidently a highly variable species, so far as its coloration is concerned, and it may. be noted that a specimen from Acajutla is described as having the 
tips of the tentacles " dark red." For the present, however, it seems advisable to regard it as distinct from the present form, but I may point out that the form described by Fewkes from Santa Barbara as Bunodes californica is in all probability assignable to Verrill's species.

\section{Genus EpIActis, Verrill.}

This genus was established by Verrill in 1869 for the reception of a form from Puget Sound which was characterized by having the young adherent to the outer surface of the column. In 1899 Verrill published a brief description of the structural peculiarities of the type, referring it to the family Cribrinida (Bunodactida) on account of its possession of a circumscribed endodermal sphincter.

It seems doubtful whether the fact that the young adhere to the column wall is sufficient for the establishment of a distinct genus, but in other respects $E$. prolifera seems to be sufficiently distinct from other Cribrinids to warrant the retention of the genus. It is one of the smooth-walled genera and differs from Leiotealia (Hertwig, '82) in the form of the sphincter and of the muscle pennon, while from Isotealia (Carlgren, '99) it is distinguished by the absence of pseudoacrorhagi.'

\section{Epiactis prolifera, Verrill.}

Synonyms.-Epiactis prolifern, Verrill, 1869. $^{4}$. Epinctis Sertilis, Andres, ${ }^{888} 3$.

The specimens in the collection were found growing upon the weeds and water grasses at Hadlock Harbor, Puget Sound.

External Form (Fig. 25).-The base is adherent. The column is marked by longitudinal grooves and more distinctly. with transverse grooves and wrinkles, probably due to contraction,

1 I am inclined to agxee with Carigren ('99) that the form I described ('93) is Lxiotealia badia is identical with bis Isotealia antarctica. In looking over my preperations I notice that in some of the sections the sphincter is decidedly nearer the margin than it is in others, though in all it is the same distance sbove the foor of the fosse. This seems to indicate the existence of the pseudoncrorhagi which Carlpren describes. But, since my preparations were made from a soull portion of a single highly contracted individual, it seems preferable to a rait a reexamination of the type, now in the U. S. National Musean, before deciding the question. 
but otherwise it is smooth and is unprovided with verrucx or tubercles. In two of the specimens embryos were adherent to the surface, and appeared as small, oval, pale bodies, in one specimen arranged in a single incomplete and interrupted circle a short distance above the limbus, a few lying a short distance above this circle in one part of the circumference, while a single one was attached high up on the column wall not far from the margin (Yig. 28, Em.). In the second specimen but one embryo occurred, situated a short distance below the margin.

The margin is quite distinct, but smooth, except for wrinkles produced by contraction, and it is separated by a slight fosse from the bases of the outer tentacles. The tentacles are moderately long and acuminate and are distinctly entacmaous. I did not succeed in making a satisfactory enumeration of them, but they are fairly numerous and appear to be arranged in five or six cycles.

The disk in the only specimen in which it could be seen was of slight extent and concave. The peristome is prominent and the lips grooved. Two gonidial grooves were distinguishable.

Color-According to Dr. Calkins' description the color is a "bright grass green or weed green" striped with darker green. Verrill apparently had no notes of the coloration of the specimens he studied, but among the drawings loaned me by $\mathbf{M r}$. Agassiz I find two which apparently represent this species. One is undoubtedly identical though it has no embryos adherent. The column is represented as bright grass green marked with longitudinal streaks of dark brown. The disk is very dark green with numerous radiating stripes of cream white and the tentacles are buff with a distinct dark greenish-brown spot at the base of each. This specimen was obtained at Crescent City. The other specimen is less certainly identical though having the same general external form. The column is dark brown streaked longitudinally with lighter brown and the tentacles are a dull grayish green. This specimen was obtained at San Rosario.

Size. The living specimens measure from 1.2 to $2.5 \mathrm{~cm}$. in diameter and the largest about $1.2 \mathrm{~cm}$. in height. The preserved 
individuals measure $1 \mathrm{~cm}$. on the average in height and about $1.2 \mathrm{~cm}$. in diameter, the base being in all cases somewhat larger than the column. Verrill's measurements of preserved specimens are identical with those just given. The tentacles in the most expanded form I examined measured $1.3 \mathrm{~cm}$. in length but in others they were only about half that length.

Structure.-The column mesogloea is thin and of a fibrous structure and its inner surface bears a well-developed layer of simple muscle processes. The inner ends of the endoderm cells are heavily laden with dense, black pigment. At the margin the endodermal musculature becomes considerably lower and on the inner wall of the fosse there is situated the sphincter. In the first individual I examined this had the form shown in Fig. 26 and was situated on the outer wall of the fosse, and from its general appearance I was led to regard it as being mesoglceal and so referred the species to the family Paractida. The publication of Verrill's description ('99) of the structure of the type and correspondence which I had with him on the subject induce me to examine the sphincter in other individuals and in these I found perfect agreement with what Verrill had described. The sphincter is of the circumscribed sessile form, situated upon the inner wall of the fosse, and has an almost circular form in cross-section; the mesogloal lamella which compose it are rather fine and anastomose more or less in places. It was evident then that the first individual that I examined either had an abnormal sphincter or eise belonged to a different species from the others. The latter possibility seems very improbable on account of the complete similarity in other respects and I conclude that the former one is correct. An extension of the area of attachment of the sphincter and a greater development of anastomoses of the lamellx would readily convert the normal sphincter into the condition shown in Fig. 26. ${ }^{1}$.

1 This figare is, accordingly, of interest only as representiog an sbnormality. The plates wete unfortunately in process of reproduction before I pereeived the error into which I bad fallen end it was not possible, therefore, to replace the figurc by a represention of the normal sphincter. 
I may add that $\mathrm{Mr}$. H. B. Torrey has recently informed me that in all the specimens of $E$. prolifere which he has examined, the sphincter was of the circumscribed sessile type.

In Fig. 27 is represented a section through a portion of the column wall bearing one of the embryos. It shows that the embryos are in an early stage of development, having just reached the stage at which the stomatodaum (st) is being invaginated. The ectoderm of the embryo (e. ec) forms a continuous sheet completely separated at every point from the ectoderm of the parent (ec) on which it rests, and it is evident that the embryos are not buds, but really egg-embryos which have become attached to the surface of the adult actinian and are held there by'the mucus $(m)$ secreted by the numerous ectodermal gland cells.

In the specimens which Verrill ('69) originally examined and which he has recently figured ('99) the attached embryos had reached a much more advanced stage of development than those just described, the smallest one having twelve tentacles and the largest twenty-four. Verrill seemed inclined, in his earlier paper, to regard the embryos as buds and states that they "probably derive nutriment from the parent." In his more recent account he evidently recedes somewhat from this position and I may point out that it seems clear from what I have stated above as to the distinct separation of the embryos from the parent that they are not nourished, by the parent in the sense that there is any communication between the cavities of the parent and those of the embryos.

The tentacles are thin-walled and their ectodermal musculature is but feebly developed. The radial musculature of the disk is fairly strong in its peripheral portions, but more centrally " it is very feeble; it is throughout ectodermal.

In the region of the lips the mesoglœa becomes considerably thickened forming ridges corresponding to the ridges of the stomatodxum. Occasionally, though not always, the tip of one of the thickenings seems to be separated from its main portion by a slight interval, producing a minute tubercle immediately external to the lips. The stomatodxum is ridged and 
there are two siphonoglyphes, one of which is much deeper than the other.

The mesenteries are arranged in four cycles with occasional representatives of a fifth. Twelve pairs are perfect in the upper part of the body, but a little farther down, even above the middle of the body, only the six primary pairs reach the stomatodzum. There are two pairs of directives.

The longitudinal musculature of the mesenteries (Yig. 28) is fairly well developed, but possesses no special features of interest; it gradually tapers off towards both edges and occupies about half the muscular portion of the mesentery at the level of the middle of the stomatodæum. The parieto-basilar in its lower part does not form a special fold, but consists of a number of processes arising directly from the surface of the outer portions of the mesenteries, but above a slight fold is visible in some of the mesenteries as shown in Iig. 28. The basilar muscle has the appearance represented in Fig. 29. All the mesenteries, with the exception of those of the first and fifth cycles, are gonophoric.

University of Michigan, February 22, 1900.

\section{LITERATURE}

Andres, $\mathbf{A}$.

'B3 Le Attinie

Fauna' u. Flora des Golfes von Neapel. Monogr. XI. $188_{3}$

Brandt, J. F.

' 35 Prodromus descriptionis animalium ab H. Mertensio observatorum. $\quad 2835$

Oarlgren, 0 .

'93 Studien uber Nordische Actinien. I Kongl. Siensk. Vet. Akad. Handl., XXV. 1893

Oarlorron, 0.

'99 Zoantharien. Hamburger Magalhaenische Sammeireise. Hamburg. 1899 
Oouthoug, J. P.

'38 Descriptions of new species of Mollusca and Shells, and remarks on several Polyps found in Massachusetts Bay Boston Joury. Nat. Hist., II. ${ }_{18} 8$

Ounninghem, J. T.

'89 Tealia tuberculata, a study in Synonomy

Dana, J, D. Journ. Marine Biolog. Assoc., N. S., I. I889

'46 Zoophytes. United States Exploring Expedition. Philadelphia. $\quad 1846$

Dawson, J. W.

'58_. On Sea-Anemones and Hydroid Polyps from the Gulf of St. Lawrence Canadian Naturalist and Geologist, III. $185^{8}$

Dicquemero, J. F.

'73 An Essay towards Elucidating the History of the SeaAnemones Phil. Trans, , lXIII. I773.

Diron,'G, Y., and A. F.

'89 Notes on Bunodes thallia, Bunodes verrucosa and Tealia crassicornis.

Sci. Proc. Roy. Dublin Soc., N. S., VI. ${ }_{1889}$

Dachasasing, P., and Micholotti, $Q$.

'60 Mémoire sur les Coralliaires des Antilles Mim. Acad. Sci. Torino, Sir. II, XIX. 1860

Duchassaing, P., and Michelotti, $O$.

'64 Supplement au Mémoire sur les Coralliaires des Antilles. Mèm. Acad. Sci. Torino, Sér. II, XXIII. $\mathrm{I}^{864}$

Duordon, J. E.

'95 On the genus Alicia (Cladactis), with an anatomical description of $A$. Costae Panc.

Ann. and Mag. Nat. Hist, Ser. 6, XV. 1895.

Duerden, J. $\mathbf{E}$.

'07 The Actiniarian Family Aliciid $\approx$

Ehrenberg Ann. and Mag. Nat. Hist, Ser. 6, XX, $18 \mathrm{~g} 7$

34 Die Corallonthiere des rothen Meeres physiologisch untersucht und systematisch verzeichnet. Berlin, 1834 Fowres, J. W.

'89 New Invertebrata from the Coast of California. Boston. 1889 
Cosse, P. E.

'65 On Peachia hastata, with observations on the family of Actiniadx

Trans. Linnean Soc, XXI. 1855

Gosse, P. E.

'60 Actinologia Britannica. London. 1860

\section{Faddon, A. 0.}

'89 A Revision of the British Actiniz. Part I

Sci. Trans. Roy. Dublin Soc. Ser. 2, IV. 1889

\section{Von Holder, $A$.}

'77 Sagartia troglodytes, ein Beitrar zur Anatomie der Actinien Sitzber. K. Acad. Wien. Math.-Nat. Cl, LXXV. 1877

\section{Hertwig, 0, $\mathrm{B}$.}

79 Die Actinien. Jena. 1879

\section{Hertwig, $\mathbf{B}$.}

'82 Report of the Actiniaria

Report on the Sci. Results of the Voy'age of H. M. S. Chal-

Hortwig, $\mathbf{B}$. lenger, Zool. Part XV. 1882

'B8 Supplement to the Report on the Actiniaria Report on the Sci. Results of the Voyage of H. M. S. Challinger. Zool. Part LXXIII. I 888

Jourdan, $\mathbf{E}$.

' 80 Recherches Zoologiques et histologiques sur les Zoanthaires. du Golfe de Marseilles Am. Sci. Nat. Zool., Gme sér., X.' I880

\section{McMurrich, J. P.}

'B9 The Actiniaria of the Bahama Islands, W. I. Journ. of Morph., III. 1889 .

McNurrich, J. $P$.

'90 Contributions on the Morphology of the Actinozoa. I. The Structure of Cerianthus Americanus

\section{MeYurtich, J. P.} Journ. of Morph., IV. ¿ 890

'93 Report on the Actinix collected by the U. S. Fish Commission Steamer Albatross during the winter of $1887-88$ Proc. U. S. Natl. Museum, XVI. 1893

\section{MeMurrich, J. P.}

'97 Contributions on the Morphology of the Actinozoa. IV Zoolog. Bull., I. 1897 


\section{Hurdock, J.}

'85 Marine Invertebrata in Report of the International Polar Expedition to Point Barrow, Alaska. Washington. $\quad \mathbf{8 8 5}$

Parker, G. H.

'97 The mesenteries and siphonoglyphs in Metridium marginatum, Milne-Edwards.

Bull. Mus. Comp. Zool., XXX. 3897

Toalo,'T. P.

'37 On the Anatomy of Actinia coriacea

Trans. Phil. Soc. Leeds, I. ${ }_{1837}$

\section{Thoroll, $\mathrm{x}$.}

'58 On den inre byggnaden af Actinia plumosa Müll.

Ofvers. $\boldsymbol{K}$. Vet. Akad. Förh. Stockholm, XV. ${ }^{3858}$

Tilesins, G. T.

'09 De nova actiniarum specie gigantea Kamtschatica Mim. Acad. Imp: St. Petersbourg, I. 1809

Vorrill, A. E.

'61 Revision of the Polypi of the Eastem Coast of the United States.

Men. Boston Soc. Nat. Hist., I. $186_{4}$

Vorrill, A. . .

'B5 Classification of Polyps Proc. Essex Inst., IV: $\rightarrow 865$

Vorrill, A. Z.

'69 Synopsis of the Polyps and Corals of the North Pacific Exploring Expedition Proc. Essex Inst., VI. $\quad 1869$

Verrill, $\mathbf{A} . \mathbf{E}$.

'69a Review of the Corals and Polyps of the West Coast of Anerica

Trans. Connecticut Acad. Arts and Sci., I. 1869

Vorrill, A. I.

'99 Descriptions of imperfectiy known and new Actinians, with critical notes on other species

Anver. Journ. Sci., VII. 1899 


\section{PLATE 1.}

(47) 


\section{PLA'TE I.}

Fig. I. 'Transverse section of sphincter of a specimen of $M c$ tridium dianthus measuring $1.5 \mathrm{~cm}$. in height (Leitz I, 3, camera),

2. Transverse section of sphincter of a specimen of Metriditm dianthus' measuring $8 \mathrm{~cm}$ in height (Leitz I, 3, camera).

3. Transverse section of sphincter of a specimen of Metriditm dianthus measuring $3 \mathrm{~cm}$. in height (Leitz I, 3, camera).

4. Transverse section of a mesentery of the first cycle of Metridium dianthus (Zeiss a, Leitz I, camera).

5. Transverse section of a directive mesentery of Metridium dianthus (Leitz I, 3, camera).

6. Transverse section of sphincter of Uricina crassicornis Leitz I, Zeiss a, camera).

7. Cribrina clegantissima, from a preserved specimen. Natural size. 
1.

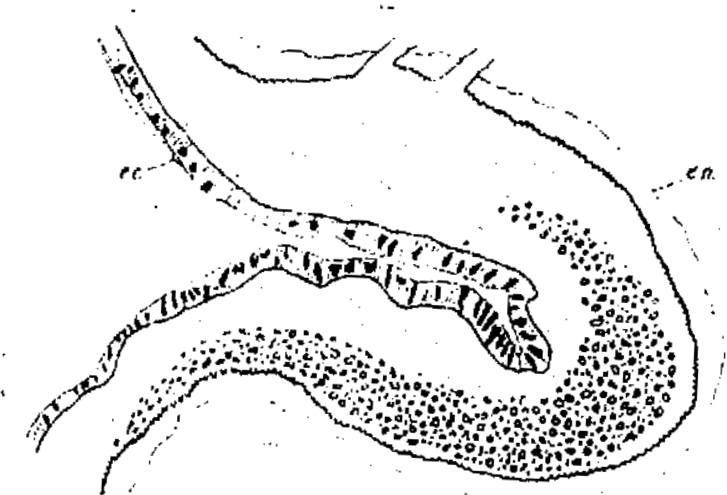

2.

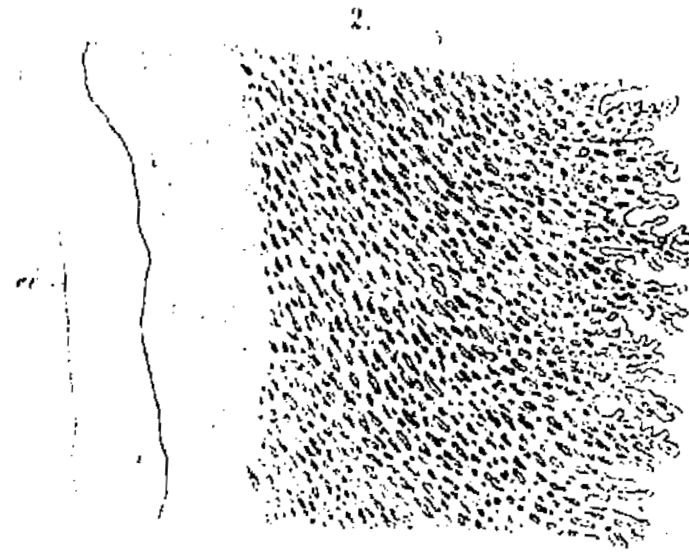

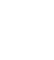

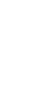




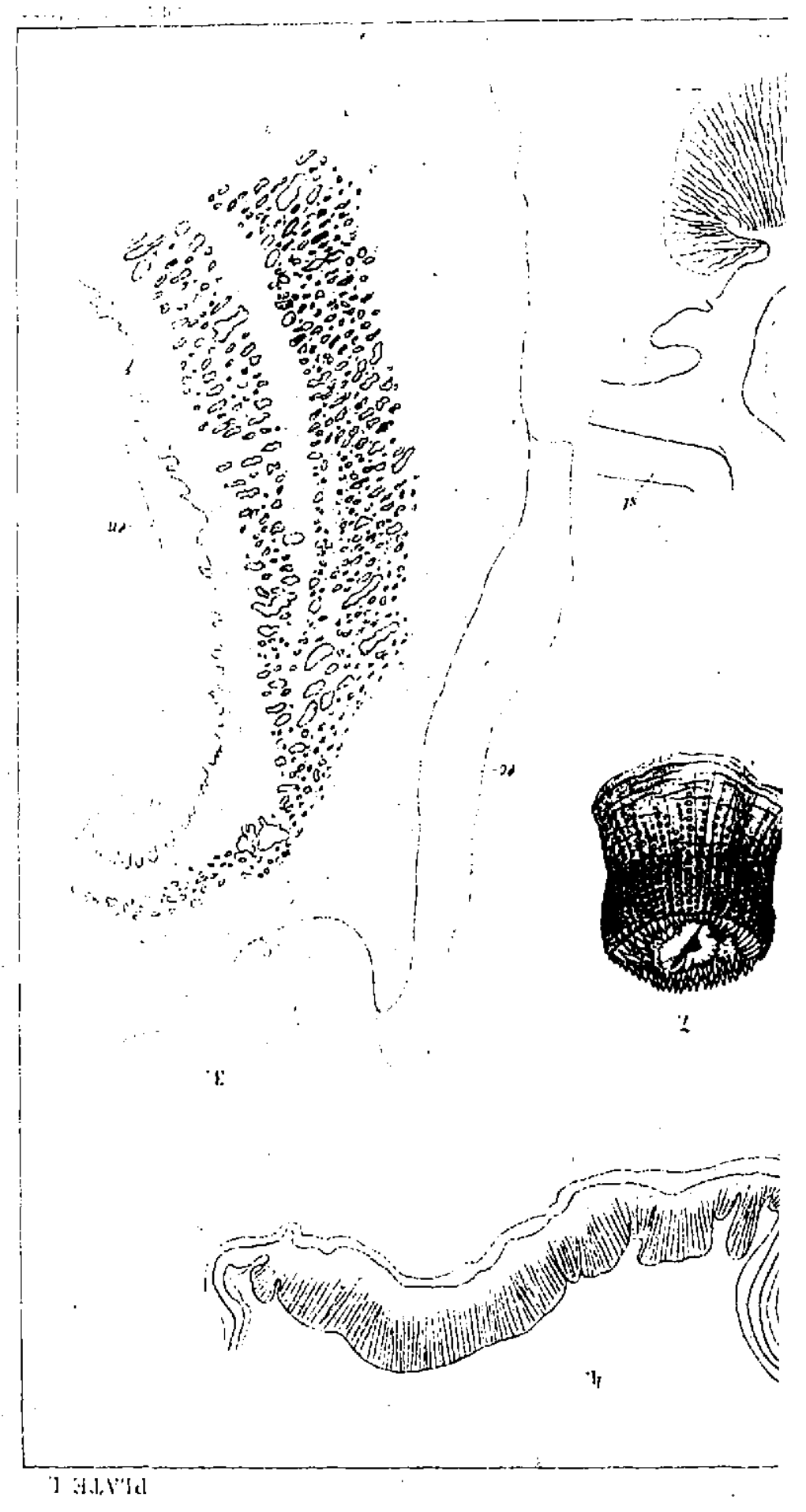




\section{PLATE II.}

(49)

ANwals N. Y. ACAD. SCI., XIV, June 5, IgoI-4. 


\section{PLATE II.}

Fig. 8. Cribrina elegantissina (drawn by Dr. G. N. Calkins).

9. Longitudinal section of upper part of the column wall: of Cribrina elegantissima. $c m=$ circular muscle at apex of verruca; $. \iota=$ column ectoderm; en $=$ col. umn endoderm; ve = modified epithelium at the apex of the verruca (Leitz I, 3, camera).

10. Transverse section of sphincter of Cribrina elegantissima (Leitz I, 3, camera).

xx. Tangential section of disk of Cribrina elegantissima (Leitz I, 3, camera).

12. Transverse section of tentacle of Cribrina elegantissima (Leitz I, 3, camera).

13. Transverse section of siphonoglyphe of Cribrina elegantissima (Zeiss a, Leitz I, csmera).

14. Transverse section of perfect mesentery of Cribrina elegantissima (Zeitz a, Leitz I, camera).

15. Cribrina artemisio from a preserved specimen. Natural size.

16. Transverse section of Cribrina artemisia (Zeiss a, Leitz I, camera).

17. Anthopleura xanthogrammica (drawn by Dr. G. N. Calkins. 


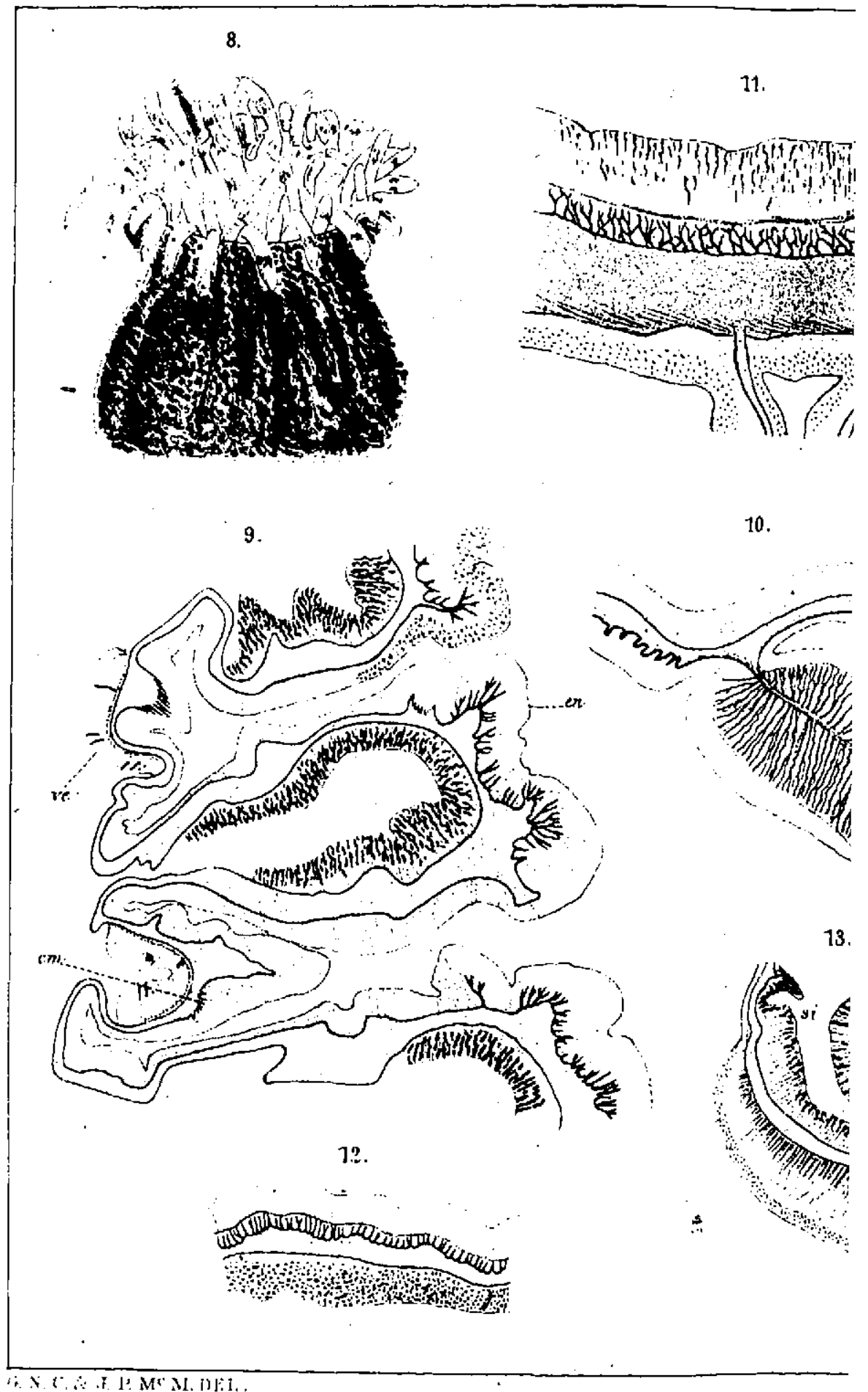



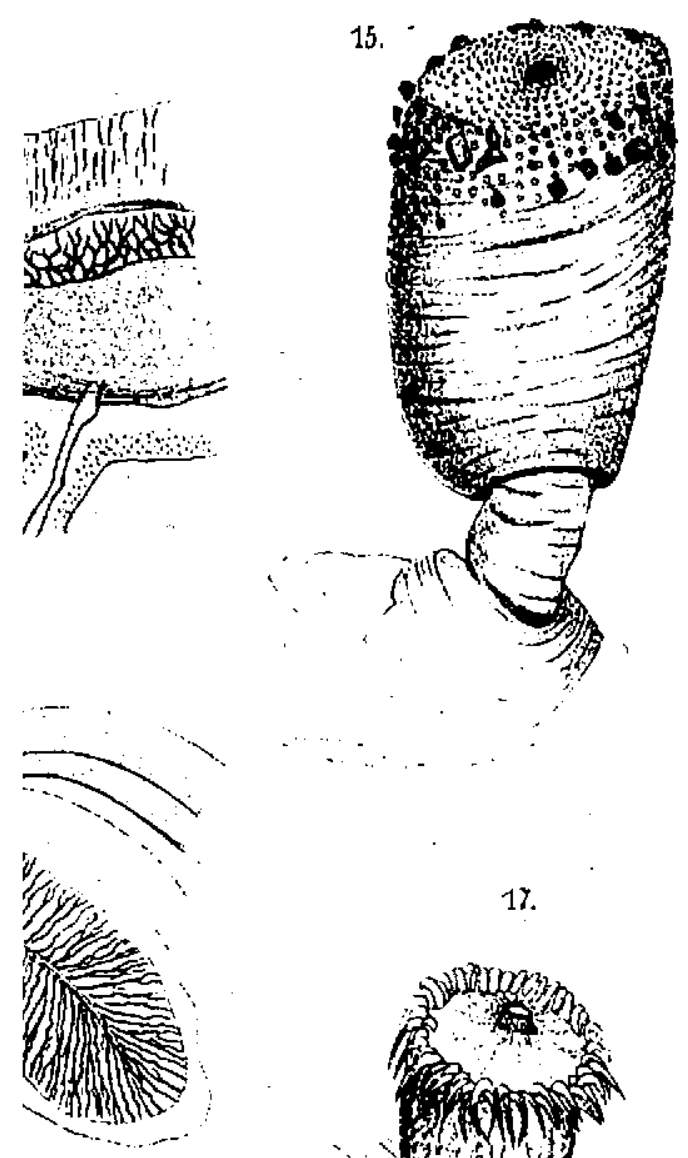

3.

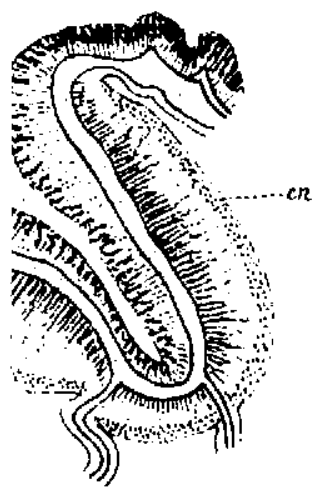

17.
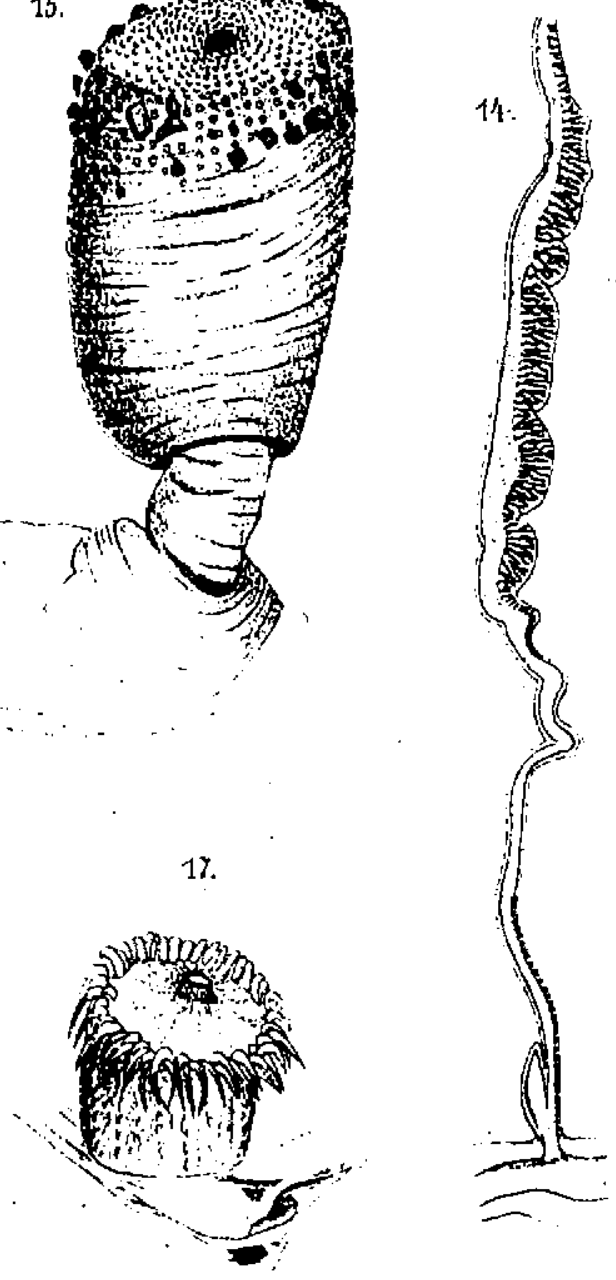

16.

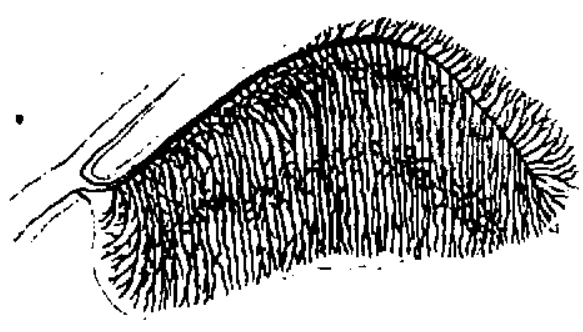

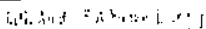


PLATE III.

(51) 


\section{PLATE III.}

18. Tangential section of disk of Cribrina artemisia (Leitz I, 3, camera).

19. Transverse section of perfect mesentery of Cribrina artemisia (Leitz I, 3, camera).

20. Transverse section of basilar muscle of Cribrina artemisia (Leitz I, 3, camera).

2I. Portion of upper part of a perfect mesentery, with disk, margin, and upper part of column in section, of Anthopleura xanthogrammica; $a c=$ acrortagus; $s p=$ sphincter ; $t=$ tentacle. $(\times 6$.

21. Transverse section of sphincter of Anthopleura xantho. gramemica (Leitz I, 3, camera).

23. Transverse section of : primary mesentery of Anthopleura xathognominica (Zeiss a, Leitz IV, camem).

24. Transverse section of basilar muscle of Anthoplaura xanthogrammica (Leitz $\mathrm{I}, 3$, camera).

25. Epiactis prolifera from a preserved specimen. $E m=$ adherent embryo (nat. size).

26. Transverse section of sphincter of Epiactis prolifera. $L=$ lower extremity of section; $U=$ upper extremity. (Leitz I, 3, camera).

27. Transverse section of a portion of the column wall of Epiactis prolifera, with an adherent embryo. $E C=$ column ectoderm; $E . e c=$ ectoderm of embryo; $E$.en $=$ endoderm of embryo; $M=$ mucus; $S t \doteq$ stomatodxal invagination. (Leitz I, 3, camera).

28. Transverse section of perfect mesentery of Epiartis prolifera. (Zeiss a, Leitz II, camera).

29. Transverse section of basilar muscle of Epiactis prolifera (Leitz I, 3, camera). 


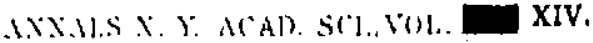

18.

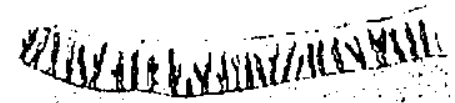

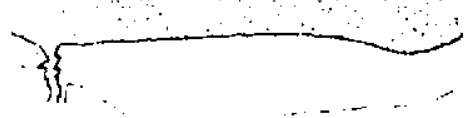

22.

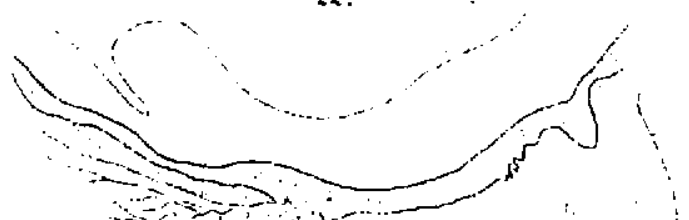

$30=0$

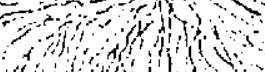

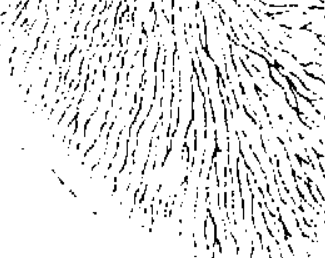
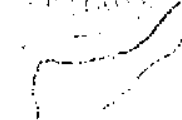

19.

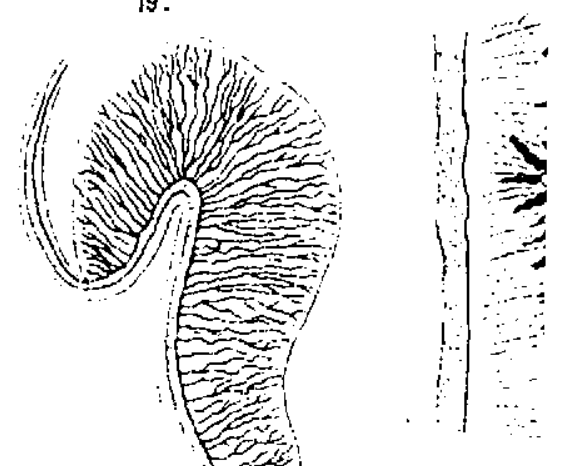




$$
4 ?
$$

